UPPSALA UNIVERSITET

Working Paper 2006:22

Department of Economics

Identifying Strategic Interactions in Swedish Local Income Tax Policies

Karin Edmark and Hanna Ågren 
Department of Economics

Uppsala University

P.O. Box 513

SE-751 20 Uppsala

Sweden

Fax: +46184711478
Working paper 2006:21

October 2006

ISSN 1653-6975

Identifying Strategic Interactions in Swedish Local Income Tax Policies

Karin EdMARK AND HanNa ÅGReN

Papers in the Working Paper Series are published on internet in PDF formats.

Download from http://www.nek.uu.se

or from S-WoPEC http://swopec.hhs.se/uunewp/ 


\title{
Identifying Strategic Interactions in Swedish Local Income Tax Policies*
}

\author{
Karin Edmark and Hanna Ågren ${ }^{\dagger}$
}

October, 2006

\begin{abstract}
This paper uses data on Swedish local governments to test for strategic interaction in tax setting. We make no a priori assumptions regarding the underlying behaviour of individuals, but instead attempt to test for the presence and type of underlying spatial process. First, we employ the estimation methods used in most earlier studies, however, we stress that these methods are limited in identifying the source of interaction. Hence, we make use of a number of additional, indirect predictions from the theories of tax competition and yardstick competition, in order to test for the presence of strategic interaction. Using such additional predictions of the theories serves a twofold purpose - first it helps us establish if the spatial coefficient is due to strategic interactions or merely reflecting spatial error correlation, and second, it helps identify the source of interaction. The analysis provides strong evidence for spatial dependence in tax rates among Swedish local governments. Moreover, we find weak evidence of tax competition or yardstick competition effects in the setting of tax rates.
\end{abstract}

Keywords: Local income tax, Spatial auto-correlation, Tax competition, Yardstick competition

JEL classifications: C52, D72, H73, H77

\footnotetext{
*We are grateful to Matz Dahlberg, Eva Mörk, Federico Revelli, Jørn Rattsø, Jon H. Fiva and Helena Svaleryd for helpful comments and suggestions. Seminar participants at Uppsala University, Gothenburg University, University of Gävle, STICERD at the London School of Economics, "Workshop on Nordic Public Economics and Taxation" in Helsinki, 2004, the 2006 Annual meeting of EEA in Vienna and at the Swedish Ministry of Finance, have also provided valuable discussions. Financial support from Finanspolitiska Forskningsinstitutet, Nordisk Skattevitenskapelig Forskningråd, The Swedish Research Council and from the Swedish Assocation of Local Authorities and Regions is gratefully acknowledged.

${ }^{\dagger}$ Department of Economics, Uppsala University, P.O. Box 513, SE-751 20 Uppsala, Sweden. Email: karin.edmark@econ.uu.se, hanna.agren@econ.uu.se
} 


\section{Introduction}

The presence of strategic interactions in the tax setting of local governments is an important issue in the organization of the public sector. Such interactions have long been investigated in theoretical economic work (see e.g. Oates (2002) or Wilson (1999) for an overview). This has resulted in two main types of theoretical frameworks: tax competition and yardstick competition. In short, the former describes a situation where local governments compete for a mobile tax base whereas in the latter, tax interaction stems from the political process. ${ }^{1}$ It can be shown that both models give rise to similar spatial reaction functions, where the tax rate of a jurisdiction is a function of that of surrounding jurisdictions, denoted neighbouring jurisdictions in the following.

Empirical work testing for strategic interactions in local tax levels is a more recent phenomenon - the first empirical studies testing for strategic interactions in the tax rate date from the mid 1990s. ${ }^{2}$ In general, the point of departure of these studies is the tax competition hypothesis, but there are also studies focusing on yardstick competition. The aggregate evidence of these studies supports the hypothesis of a spatial pattern in the tax rates of local jurisdictions. The size of the interaction varies quite substantially, however, and compared to the theoretical literature, the empirical work is quite scarce. ${ }^{3}$

This paper tests for strategic interactions in the tax setting behaviour of local governments in Sweden. We recognize that the estimation methods are limited in identifying the source of interaction. ${ }^{4}$ In contrast to many studies in this field, we make no a priori assumptions regarding the underlying theoretical framework. Instead, we make use of additional, indirect predictions from the theories of tax competition and yardstick competition to test for the presence of strategic interaction in these forms ${ }^{5}$. Specifically, we use a reform of the central government grants system, which changed the system of tax base equalization of the municipalities, to test for tax competition. The idea is that if we find the degree of interaction to be different after the reform, this can be seen as indirect evidence of tax competition. We also use two empirical implications descending from yardstick competition; namely that yardstick-type interaction is expected to be more prevalent during election years and when the political majority is weak, to test for strategic interaction in the form of yardstick competition.

\footnotetext{
${ }^{1} \mathrm{~A}$ more detailed description of these models is given in section 2 .

${ }^{2}$ See e.g. Besley and Case (1995); Bordignon et al (2003); Brett and Pinkse (2000); Brueckner and Saavedra (2001); Buettner (2001); Esteller-Moré and Solé-Ollé (2002); Heyndels and Vuchelen (1998) and Revelli (2001).

${ }^{3}$ See e.g. Allers and Elhorst (2005) for a summary of a number of results in recent studies.

${ }^{4}$ This will be discussed in greater detail in sections 3 and 6 .

${ }^{5}$ These tests will be thoroughly described in section 6 .
} 
In addition, we estimate a number of alternative specifications of the tax interactions equation, where we vary the criterion for defining a municipality's reference group. By specifying a set of alternative "neighbourhood criteria", that to different degrees correspond with the theories of tax and yardstick competition respectively, we can get an additional indication of which form of interaction is taking place.

Given the difficulties in ensuring identification through standard estimation, we believe that using these forms of indirect identification strategies is a fruitful way to proceed, both to separate strategic interactions from potential bias stemming from spatial error correlation and to separate between the different underlying theories.

Due to the simultaneity of the interaction between a municipality and its reference group, we estimate the tax interaction equation with 2SLS, using a subset of neighbours' characteristics as instruments for the tax rate of the reference group. This is a procedure often used in the literature on strategic interactions.

Swedish data is highly suitable for testing strategic interactions in local tax setting. The local governments are responsible for the provision of essential welfare services ${ }^{6}$ and have a high degree of autonomy both when it comes to the right to decide on the provision of local public services and their right to set the local income tax rate. Tax revenue constitute the bulk of total revenues and the degree to which citizens depend on municipal services along with the heavy reliance on tax revenues make tax policy a salient issue in local policy making. Furthermore, the institutional setting combines the vast decentralization in the provision and financing of important public services with a grants system which, to a large degree, equalizes the economic conditions of the local governments. A system that equalizes the taxbase naturally reduces the motives for tax competition. Therefore, we expect to find less tax competition than in countries with a less redistributive system. Given this institutional setting, it is interesting to compare the results of a highly decentralized but also equalized country to those of other countries.

The main results can be summarized as follows. The analysis provides evidence of spatial dependence in the tax rates among Swedish local governments: a tax cut of on average 1 percentage point in neighbouring jurisdictions leads to a decrease of about 0.79 percentage points in own taxes, which is of the same magnitude as that found in similar studies on interdependence in tax setting. The result is robust to using different specifications of neighbourhood, that are derived from the tax competition and yardstick competition theories respectively. This suggests that there is a spatial pattern in the data that is consistent with the predictions from these theories.

Using additional indirect identification strategies that are consistent with either the tax competition or the yardstick competition framework, the paper finds no (when

\footnotetext{
${ }^{6}$ The municipalities are responsible for the provision of services such as care of the elderly, child care and education.
} 
accounting for dynamics by clustering on municipality), or weak (when not clustering) evidence supporting that the spatial auto-correlation in taxes among Swedish local governments can be explained by electoral concerns or incentives to attract mobile taxpayers, as suggested by the theories on strategic tax interaction.

The remainder of the paper is organized as follows. Section 2 provides a basic description of the two theoretical models of tax interaction: the tax competition model and the yardstick competition model. Section 3 discusses the methodology used in the empirical analysis. In Section 4, we present the data and describe the institutional setting. Section 5 turns to the empirical specification of the tax reaction function and the baseline results. In addition, Section 5 contains a description of, and results using alternative definitions of neighbourhood. In Section 6, we turn to the identification of strategic interaction using the grants reform as well as features of the electoral system. Finally, Section 7 concludes.

\section{Theoretical background}

This section will give a basic description of the two theoretical models of tax interaction: the tax competition model and the yardstick competition model. They are similar in the sense that the tax setting of the decision-maker of a local jurisdiction is restricted by the neighbouring municipalities' tax rates. The underlying interactionmechanisms differ, however. The section draws heavily on Brueckner (2003) and Revelli (2005).

We start by defining the objective of the decision-maker in jurisdiction $i$ as choosing the optimal local policy, here tax level $\tau_{i}$, given a set of jurisdiction-specific characteristics, $X_{i}$ :

$$
V\left(\tau_{i} ; X_{i}\right) .
$$

Taking equation (1) as our point of departure, we now turn to describing tax competition and yardstick competition, respectively. The objective of equation (1) is indeed very simple. It assumes a constant tax base, i.e. taxable resources are immobile, and it does not model the political process. These two issues are precisely what the tax competition and the yardstick competition models deal with.

\subsection{Tax competition}

The tax competition model differs from the baseline objective of equation (1) in that the tax base is assumed to be mobile. In particular, it is assumed that tax payers move where taxes are lower, ceteris paribus. The tax base of jurisdiction $i$, here denoted $s_{i}$, is hence a function of the relation between the tax level in the own and the neighbouring regions, $\tau_{i}$ and $\tau_{-i}$ respectively, as well as of other factors influencing 
the decision to move, $X_{i}$ :

$$
s_{i}=s\left(\tau_{i}, \tau_{-i}, X_{i}\right)
$$

If we include the tax base in the objective function of equation (1), we obtain the objective function of the tax competition model. Inserting equation (2) yields the following expression:

$$
\begin{aligned}
V^{t}\left(\tau_{i}, s_{i} ; X_{i}\right) & =V\left(\tau_{i}, s\left(\tau_{i}, \tau_{-i}, X_{i}\right) ; X_{i}\right) \\
& =V\left(\tau_{i}, \tau_{-i}, X_{i}\right)
\end{aligned}
$$

Maximizing equation (3) w.r.t the own tax level, it is easily seen that the optimal tax level of jurisdiction $i$ will be a function of the neighbouring jurisdictions' tax levels, in addition to own characteristics, $X_{i}$

$$
\tau_{i}=\tau\left(\tau_{-i}, X_{i}\right)
$$

The underlying assumption driving interaction in the tax competition model is hence the mobility of the tax base, as illustrated in equation (2). It can be shown that the fact that the tax base responds negatively to the relative tax rate puts a downward pressure on the tax rate, which leads to taxes being set suboptimally low compared to the social optimum.

\subsection{Yardstick competition}

While the tax competition model adds the assumption of mobile taxable resources to the baseline case, the yardstick model takes into account the electoral process. As in the baseline objective, the yardstick model assumes an immobile tax base. Tax interaction in this model stems from the assumption that voters evaluate politicians by comparing their performance with that of neighbouring jurisdictions.

In the yardstick competition model, the tax policy of a jurisdiction is derived from the incumbent's objective, which is to maximize personal rents ${ }^{7}$ over a period of two terms in office. The incumbent maximizes the sum of the utility of rents in each period, $v\left(w_{i, t}\right)$ and $v\left(w_{i, t+1}\right)$, taking into account that the probability of being re-elected for a second period is $p_{i}$

$$
V_{i}^{y}=v\left(w_{i, t}\right)+p_{i} v\left(w_{i, t+1}\right)
$$

The rents in period $i, w_{i}$, are equal to the difference between tax revenue $\tau_{i}$, and the cost of providing public service, $c_{i}$, which, in turn, we assume to be determined by the jurisdiction-specific characteristics, $X_{i}$

$$
\begin{aligned}
w_{i} & =\tau_{i}-c_{i} \\
& =\tau_{i}-c\left(X_{i}\right)
\end{aligned}
$$

\footnotetext{
${ }^{7}$ Rents can broadly be seen as inefficiency, i.e. they can, for example, be shirking by politicians or other forms of waste.
} 
It is in the voters' interest to limit the amount of rents extracted, to ensure that the tax revenue is allocated to public services and not to personal rents. The problem is that voters cannot observe the true cost of provision of public services and hence, do not know whether the tax level set by the local politician is motivated by the costs of public provision, or if part of the tax revenue is wasted on personal rents.

The yardstick competition model assumes the voters to deal with this asymmetric information problem by comparing the levels of taxes and public service to those of neighbouring jurisdictions. The rationale behind this is that the jurisdictions located in the same region are likely to be subject to similar economic circumstances and hence, are also likely to have roughly the same costs for provision of public services. Consequently, they should require about the same level of taxes to provide a given level of service ${ }^{8}$.

This comparative performance evaluation implies that a politician increasing the tax rate relative to that of the surrounding jurisdictions, without proportionally increasing public service, will be punished by the voters in the next election. The probability of re-election $p_{i}$ is hence dependent on the tax level of the own and neighbouring jurisdictions, taking into account a set of jurisdiction-specific factors:

$$
p_{i}=p\left(\tau_{i}, \tau_{-i} ; X_{i}\right)
$$

Inserting equations (6) and (7) in the yardstick objective (5), we obtain the following expression:

$$
V_{i}^{y}=v\left(\tau_{i}-c\left(X_{i}\right)\right)+p\left(\tau_{i}, \tau_{-i} ; X_{i}\right) v\left(\tau_{i, t+1}-c\left(X_{i, t+1}\right)\right)
$$

If, for simplicity, we assume the expectations of $\tau_{i, t+1}$ and $c_{i, t+1}$ to be equal to the current values, we can write the yardstick objective as a function of the tax levels in the own and neighbouring jurisdictions and of a set of jurisdiction-specific characteristics:

$$
\begin{aligned}
V_{i}^{y} & =V\left(\tau_{i}, p\left(\tau_{i}, \tau_{-i} ; X_{i}\right) ; X_{i}\right) \\
& =V\left(\tau_{i}, \tau_{-i},, X_{i}\right) .
\end{aligned}
$$

We see that the resulting reduced form objective is equal to that obtained from the tax competition model. Hence, the yardstick model results in a tax reaction function similar to that of equation (4). In this case, the interpretation of the tax reaction function is that the incumbent will ensure not to deviate too much from the levels set in the neighbouring regions, since this will have a negative effect on her chances of being re-elected. In general, yardstick competition thus gives rise to positive tax interaction. However, as shown by Bordignon et al. (2004), under certain circumstances, yardstick competition can also lead to a negative correlation among

\footnotetext{
${ }^{8}$ For example, they are likely to be affected by the same macroeconomic shocks.
} 
the taxes of neighbouring jurisdictions. ${ }^{9}$

Compared to the tax competition model, spatial interaction in the yardstick framework is a result of the electoral process, and not of mobile tax payers. These differences are important if we consider the policy implications of the models. Whereas the tax competition model resulted in taxes being set too low, in the yardstick competition model, the comparative performance evaluation of the voters restricts wasteful (or inefficient) behaviour on behalf of the incumbent. Hence, the behaviour driving the interaction in the yardstick competition model increases the efficiency of public service provision. Therefore, it is an important task to not only investigate whether there are strategic interactions, but also to test for the type of interaction. One way of doing this is to link tax setting behaviour to external information regarding the framework or rules under which the municipalities operate, which is only consistent with one of the theoretical interaction models. We will return to this issue in section 6 .

\section{Methodology}

As shown in the previous section, the source of horizontal interaction in the theoretical framework depends on the assumptions made about individuals' underlying behaviour. We also saw that the derived reaction function will be the same, irrespective of whether the citizenry is assumed to react to tax policy differences by migrating (i.e. voting with their feet) or if immobile voters, at the polls, punish their elected politicians by ousting them from office. Assuming linearity, the tax reaction function in equation (4) can be written in regression vector form as:

$$
\tau=\theta W \tau+\beta^{\prime} X+\epsilon
$$

where $\tau$ is a vector of the municipal tax rate, $W$ is a neighbour weight matrix which gives positive weight to the policy values of neighbouring municipalities, so that $W \tau$ gives the average tax rate of the municipalities that are defined as neighbours. $X$ is a matrix of municipality-specific characteristics that affect the policy decision (here also including a vector of constants), and $\epsilon$ is a vector of regression error terms. A non-zero coefficient for the neighbours' tax rates is consistent with the theories of tax competition and yardstick competition, as shown in section 2 .

The issue of how $W$ is determined deserves a comment. Due to lack of degrees of freedom, matrix $W$ cannot be estimated, but must be defined a priori. In general, the weighting criterion should be based on theoretical foundations. However, this may lead to imposing a spatial structure on the data that is in line with the problem to

\footnotetext{
${ }^{9}$ They show this to be the case if the reelection chances of a bad government are so low that, given low taxes in neighbouring jursdictions, it will be preferable to accumulate the maximum rent in the first period in office by raising the local tax rate and hence, not be reelected. For details, see Bordignon et al. (2004).
} 
be investigated. A "neutral" and commonly used criterion is to define jurisdictions that share a border as neighbours. This is a simple definition capturing the idea of interaction being more likely to take place between closely situated jurisdictions. We will use this definition in our baseline regressions, but will in section 5.2 also use alternative neighbourhood criteria that to a varying degree correspond to the theories of strategic tax interaction (see section 5.2 for the definitions in detail).

There are two main methodological challenges in estimating an equation of type (8). First, we need to account for the simultaneity in tax determination, which implies that standard OLS yields inconsistent and biased estimates of $W \tau$. Second, we need to ensure that the interaction coefficient does not suffer from bias due to omitted variables/spatial error correlation.

The literature on spatial interactions suggests two methods for dealing with this estimation problem: instrumental variable analysis (IV) and maximum likelihood (ML) spatial lag estimation (see Anselin (1988) or Revelli (2005) for a thorough description of spatial estimation methods).

As shown by Kelejian and Prucha (1998), given that the instrument is valid, IV produces consistent estimates in the presence of spatially correlated errors. A benefit of the IV-technique is hence that it enables us to separate the spatial interaction effect from potential spatial correlation in the error term. In contrast, the scope for separately identifying interaction in the dependent variable with ML-estimation, when the error term is also spatially correlated, is weak. ${ }^{10}$ Another, more practical, disadvantage with the spatial lag ML-estimator is that it is computationally highly demanding, especially when dealing with panel datasets. Due to these problems, we will use IV for our estimations. For comparison, however, we will also show some cross-section results (in section A.4, Appendix) from estimating spatial lag ML.

Following the idea proposed by Kelejian and Robinson (1993), and following several studies similar to this (see e.g. Besley and Case (1995), Heyndels and Vuchelen (1998), Revelli (2001) and Solé-Ollé (2003)), we will use a subset of neighbours' covariates, $W X$, as instruments for the interaction variable.

\section{Data and institutional setting}

To investigate the existence of horizontal interaction in tax setting, we use data on a panel of Swedish local governments during 1993-2003. Before describing the data, we will briefly comment on the Swedish institutional setting. The Swedish public sector is organized into three layers of government: national, county and municipal levels.

\footnotetext{
${ }^{10}$ While the ML-estimator can, in principle, be used to simultaneously estimate spatial processes in both the error term and the dependent variable, it is arguable how successful they are in separately identifying these processes.
} 
The local units are responsible for the provision of important welfare services: the Swedish municipalities supply education, child care, social assistance and care for the elderly, while medical care and public transport are organized at the county level ${ }^{11}$. The focus here is on the municipalities. ${ }^{12}$

Swedish municipalities have the constitutional right of self government. The degree of autonomy refers both to their right to decide on the provision of local public services and their right to set the local income tax rate (note that only income is taxed locally - property taxes, for example, are set at the national level). Moreover, they are not limited by borrowing constraints. ${ }^{13}$

The local income tax, which is a proportional tax rate, generates the main source of the municipalities' own revenues: tax revenue as a fraction of total revenues amounts to about 70 percent $^{14}$. A small proportion, 15 percent on average, consists of central government grants. The degree to which citizens depend on municipal services and the heavy reliance on tax revenues make tax policy a salient issue in local policy making.

The choice of time period deserves a comment. During the 1990s, a number of regulations and institutional changes took place. For example, between 1991-1993, the central government imposed a temporary tax cap on the municipal tax rate. In addition, the responsibility for providing care for the elderly was shifted from the county to the municipal level in 1992 , leading to an increase in municipal tax rates. ${ }^{15}$ Hence, we use data for the period 1993-2003.

Sweden consists of 290 municipalities. However, there has been a number of mergers and secessions during the period of our study. Consequently, seven municipalities subject to these changes have been excluded from the data, resulting in 283 municipalities. ${ }^{16}$

\footnotetext{
${ }^{11}$ In two municipalities, Malmö and Göteborg, the municipalities are also responsible for the county-level tasks.

${ }^{12}$ Personal income is also taxed at the county level. This implies that there may also be vertical interactions in the tax rates (see e.g. Revelli (2005)). This is tested by including county taxes as a covariate in the baseline regression (treating the county tax rate as exogenous). The results, which are shown in Table A.3 in the Appendix, show county tax to have a negative (indicating substitutes) but insignificant effect on the municipal tax rate. The interaction coefficient decreases somewhat, but is not significantly different from the baseline result when county tax is not included in the regression.

${ }^{13}$ In 2000, a balanced budget rule was introduced. However, it is not clear that the introduction of a balanced budget rule has had any real effect.

${ }^{14}$ This figure is for 2002, see "Kommunernas ekonomiska läge", Svenska Kommunförbundet, April 2003 .

${ }^{15}$ In 1995, part of the responsibility for the care of the mentally ill was directed to the local authorities. This is a minor change, however, as compared to the changes taking place in 1992. Any effects of this on the tax interaction will be captured by the inclusion of year effects, to the extent that they have a similar effect on all municipalities.

${ }^{16}$ The excluded municipalities are Bollebygd, Gnesta, Lekeberg, Nykvarn, Knivsta and Trosa.
} 
The empirical analysis will include a large set of covariates capturing the economic and demographic complexion of the municipalities. These variables are: municipal income tax rate, taxable income, grants, unemployment, the proportion of young and old (defined as the share of the population aged 0-15 and 65+ respectively), population size, and the share of the population on welfare. Sweden is commonly treated as a bipartisan electoral system with either a left-wing or a right-wing majority. ${ }^{17}$ The data includes the number of votes for the ruling party coalition (left or right) in the three local elections during the sample period. ${ }^{18}$ The fiscal variables, intergovernmental grants and taxable income, are intended to capture the demand and need for locally provided services. The rate of unemployment as well as taxable income can be seen as controls for local business cycle variations. ${ }^{19}$ The proportion of young (0-15) and old (65 and over), as well as the share on welfare, are included to capture the costs of local government spending. Furthermore, population size is included to control for possible economies of scale in the provision of locally provided services. We include a dummy variable (left-wing), indicating the party affiliation of the majority in power, to control for systematic differences in the tax setting between left- and right-wing local governments.

Table 1 provides some descriptive statistics of the included variables. All monetary variables are in SEK and have been deflated to the 2002 year price level, while the variables defined as proportions are shown as percentage points.

Table 1 shows the municipal tax rate to average 20.6 percent over the period, with a minimum at 13 and a maximum at 31 . However, the great difference between the min and max value is due to the fact that in two of the municipalities in our sample, Malmö and Göteborg, the services otherwise organized at the county level, are provided by the municipality. If these two municipalities are excluded, the maximum value for the tax level decreases to 23.6 percent. ${ }^{20}$

\footnotetext{
Moreover, the island of Gotland is excluded due to the obvious difficulty in identifying neighbours.

${ }^{17}$ See e.g., Alesina et al. (1997) and Pettersson-Lidbom (2003). Following the categorization in Peterson (1992), the left-wing parties are the Left Party and the Social Democratic Party, and the parties characterized as right-wing are the Conservative Party, the Centrist Party, the Liberal Party and the Christian Democratic party (a fifth party, New Democracy, was added in 1991).

${ }^{18}$ The election years are 1994, 1998 and 2002.

${ }^{19}$ While it is true that in the tax competition theory, the effect of the taxbase is channeled solely through the interaction among jurisdictions and hence should have no independent effect on the local tax rate (see section 2.1), we acknowledge that the taxable income can change for other reasons than migration, and therefore include the variable as a covariate.

${ }^{20}$ Since these municipalities are large and possibly important in terms of strategic interactions, we will keep them in the sample. The difference in tax rates for these municipalities due to additional responsibilities will be captured by the inclusion of municipality-specific fixed effects.
} 
Table 1: Descriptive Statistics 1993-2003

\begin{tabular}{lccccc}
\hline \hline Variable & Obs & Mean & Std & Min & Max \\
\hline Income tax rate \% & 3113 & 20.6 & 1.6 & 13.2 & 31.3 \\
Taxable income & 3113 & 102,200 & 16,600 & 67,200 & 245,900 \\
Grants & 3100 & 8,443 & 4,207 & $-15,404$ & 25,029 \\
Unemployment \% & 3113 & 5.6 & 2.5 & 0.9 & 13.8 \\
Proportion young (0-15) & 3113 & 19.1 & 1.7 & 13.3 & 24.9 \\
Proportion elderly (65+) & 3113 & 18.8 & 3.8 & 5.9 & 30 \\
Population size (per 1000) & 3113 & 30.9 & 56.8 & 2.6 & 758.1 \\
Share on welfare & 3098 & 5.9 & 2.3 & 0.5 & 16.3 \\
Party affiliation & 3113 & 0.40 & 0.49 & 0 & 1 \\
\hline
\end{tabular}

The grants variable is defined as total grants per inhabitant and contains equalization grants as well as general grants. The negative minimum value of this variable reflects the fact that some municipalities ended up as negative grants-recipients after a reform of the intergovernmental grant system in 1996 (more about this in section $6)$.

As can be seen in Table 1, there are a few missing observations for grants and the share of the population on welfare. Our analysis is performed on the unbalanced panel (with a total of 28 missing observations).

Before moving on to the regression analysis, we want to test whether a spatial analysis is also motivated by looking at the data. We use the Moran I-statistic (see Cliff and Ord (1981)), a test commonly used in the spatial econometrics literature to test for a spatial pattern in the data. ${ }^{21}$

The results, which are reported in section A1, Appendix, show that a spatial analysis is indeed motivated: First, the test indicates a positive spatial pattern in the tax rates of the municipalities, which is consistent with our interaction hypothesis. Second, we are also interested in whether a spatial pattern is present when other factors included in our tax rate specification are controlled for. We therefore test for a spatial pattern in the residuals from the regression equation (9) when we exclude the tax interaction term $\theta W \tau$. The test results indicate a negative spatial pattern in the error term of this specification. This suggests that there may be negative spatial processes, in addition to the potential positive tax interaction. This speaks for using IV since, as discussed in section 3, the IV-estimator is robust to spatial error correlation.

\footnotetext{
${ }^{21}$ The Gauss-code we use to compute the Moran I-statistic was generously provided by Federico Revelli.
} 


\section{Specification of the tax reaction function}

As specified in section 2, our estimating equation can be written as:

$$
\tau=\theta W \tau+\beta^{\prime} X+\text { year }+i d+\epsilon,
$$

where $\tau$ is the local income tax rate and $W \tau$ the average of neighbouring municipalities' tax rates, based on the common border criterion. ${ }^{22}$ The empirical specification includes a rich set of covariates, as specified above. These are included in matrix $X$ of equation (9). Finally, the specification includes a set of yearly dummy variables, year, to control for time-varying influences common to all municipalities in a certain year, and for municipality-specific fixed effects, $i d$, to control for time-invariant municipality-specific factors.

As discussed in section 2, a non-zero $\theta$-coefficient is consistent with strategic tax interactions. In the tax competition case, we expect the coefficient to be positive, while in the yardstick competition framework, both a positive and a negative coefficient are possible.

\section{$5.1 \quad$ Baseline results}

Taking into account the endogeneity of the interaction variable, we will estimate equation (9) by IV. As discussed in section 3, IV has the advantage of being consistent also in the presence of spatial error correlation. This is an important aspect, since spatial error dependence was indicated in the preliminary test for spatial dependence.

Following Kelejian and Robinson (1993), we select a subset of spatially lagged covariates as instruments to obtain consistent estimates of the interaction parameter. ${ }^{23}$ The variables we use as instruments are the neighbours' unemployment rate and neighbours' share of welfare recipients. The estimating equation includes own municipality tax policy determinants, hence the interaction coefficient is identified using the difference in the variation between the own and neighbouring municipality characteristics that are used as instruments. Including the additional set of covariates can furthermore be seen as a means to increase the probability that our instruments are valid. The idea is that by including the municipality characteristics, we require that the instruments are valid, not unconditionally, but conditional on the covariates.

There are several reasons for only using a subset of the covariates as instruments. For example, in the tax competition model described in section 2, the tax base of

\footnotetext{
${ }^{22} W$ is a spatial weight matrix (Anselin (1988)), where the elements take on a non-zero value for neighboring municipalities, and zero otherwise. By row-standardizing the spatial matrix, the average is independent of the number of neighbours (Case et al. (1993)). In addition to the border criterion, we define alternative weight-matrices in section 5.2 .

${ }^{23}$ For studies using an IV approach when testing for spatial auto-correlation in taxes, see e.g. Besley and Case (1995), Buettner (2001), Esteller-Moré and Solé-Ollé (2002), Heyndels and Vuchelen (1998), and Revelli (2001).
} 
neighbours will clearly be endogenously determined by the own tax rate, in case residents react to tax differences by relocating. Similarly, due to the previously mentioned intergovernmental grants system, grants may not be considered as an appropriate instrument, since it could be that the effect of grants is taken into account in the local tax decision. In addition, we want to avoid small sample over-fitting bias; hence, we will use a small set of covariates as instruments. ${ }^{24}$ Since tax rates are persistent, we, in addition to heteroscedasticity consistent standard errors, allow for arbitrary serial correlation within municipality. This is handled by clustering the standard errors at the municipality level, as suggested by e.g. Kézdi (2002) and Bertrand et al. (2004). We acknowledge however, that this is restrictive considering the rather limited variation within municipality and henceforth, both standard errors robust to heteroscedasticity (within parenthesis) and, robust to heteroscedasticity and serial correlation (within brackets) are reported.

Turning to the estimations, Table 2 presents the estimation results. Column 1 of Table 2 shows the OLS results, treating $W \tau$ as exogenous, and column 2 shows the baseline IV results using the unemployment rate and the share of welfare recipients as instruments for neighbours' tax rates. The table shows the coefficient on the spatially weighted average of neighbours' tax rates to have a positive and significant effect on the own tax rate in all specifications. Comparing columns 1 and 2, we see that the effect is even larger when treating own and neighbours' tax setting as a simultaneous decision. The coefficient is 0.79 , implying that an average tax decrease (increase) of one percentage point among neighbouring municipalities, induces a 0.79 percentage point decrease (increase) in the own tax rate. ${ }^{25}$

The fact that the IV-estimate is higher than the OLS-correspondence may seem puzzling, considering that we expect the simultaneity bias of the OLS-estimate to be positive. A possible explanation for the lower OLS-coefficient is that it also suffers from a downward bias, due to negative spatial error correlation, something which is supported by the result of the Moran I-statistic in section 4.

Turning to the covariates, the results in column 2 show that the coefficient on the tax base is positive and significant, indicating that an increase in average income is

\footnotetext{
${ }^{24}$ See e.g. Staiger and Stock (1997) for a discussion on small sample over-fitting bias and problems related to weak instruments.

${ }^{25}$ As previously noted, adding county income tax rates to account for possible vertical interactions does not change the results of the baseline specification, see Appendix Table A.3. In addition, including linear county-specific trends to account for common shocks within counties, does not qualitatively change our baseline result (results not shown).
} 
Table 2: Baseline estimation of the tax reaction function

\begin{tabular}{|c|c|c|}
\hline & $\begin{array}{c}\text { OLS } \\
(1)\end{array}$ & $\begin{array}{l}\text { IV } \\
(2)\end{array}$ \\
\hline \multirow[t]{2}{*}{ Neighbours' tax rate } & $\begin{array}{c}0.502 \\
(0.033) * * *\end{array}$ & $\begin{array}{c}0.794 \\
(0.134) * * *\end{array}$ \\
\hline & {$[0.081] * * *$} & {$[0.207] * * *$} \\
\hline \multirow[t]{2}{*}{ Taxable income } & $\begin{array}{c}0.005 \\
(0.0007) * * *\end{array}$ & $\begin{array}{c}0.005 \\
(0.0007) * * *\end{array}$ \\
\hline & {$[0.001] * * *$} & {$[0.001] * * *$} \\
\hline \multirow[t]{2}{*}{ Grants } & $\begin{array}{c}0.00002 \\
(1.00 \mathrm{e}-05) *\end{array}$ & $\begin{array}{c}0.00002 \\
(1.00 \mathrm{e}-05) *\end{array}$ \\
\hline & {$[0.00002]$} & {$[0.00002]$} \\
\hline \multirow[t]{2}{*}{ Unemployment rate } & $\begin{array}{c}0.034 \\
(0.011) * * *\end{array}$ & $\begin{array}{c}0.022 \\
(0.012) *\end{array}$ \\
\hline & {$[0.018] *$} & {$[0.019]$} \\
\hline \multirow[t]{2}{*}{ Population size } & $\begin{array}{c}-0.098 \\
(0.029) * * *\end{array}$ & $\begin{array}{c}-0.095 \\
(0.028) * * *\end{array}$ \\
\hline & {$[0.069]$} & {$[0.067]$} \\
\hline \multirow[t]{2}{*}{ Proportion of young (0-15) } & $\begin{array}{l}0.013 \\
(0.027)\end{array}$ & $\begin{array}{c}0.05 \\
(0.034)\end{array}$ \\
\hline & {$[0.053]$} & {$[0.07]$} \\
\hline \multirow[t]{2}{*}{ Proportion of elderly $(65+)$} & $\begin{array}{c}0.094 \\
(0.022) * * *\end{array}$ & $\begin{array}{c}0.133 \\
(0.028) * * *\end{array}$ \\
\hline & {$[0.043] * *$} & {$[0.053] * *$} \\
\hline \multirow[t]{2}{*}{ Share of welfare recipients } & $\begin{array}{c}-0.001 \\
(0.012)\end{array}$ & $\begin{array}{l}0.007 \\
(0.014)\end{array}$ \\
\hline & {$[0.021]$} & {$[0.023]$} \\
\hline \multirow[t]{2}{*}{ Left-wing } & $\begin{array}{c}-0.043 \\
(0.03)\end{array}$ & $\begin{array}{c}-0.046 \\
(0.031)\end{array}$ \\
\hline & {$[0.033]$} & {$[0.032]$} \\
\hline Year effects & yes & yes \\
\hline Fixed effects & yes & yes \\
\hline F-test & & 11.97 \\
\hline Hansen J (p-value) & & 0.483 \\
\hline Obs. & 3085 & 3085 \\
\hline
\end{tabular}

Note: The dependent variable is the municipal tax rate. Standard errors robust to heteroscedasticity are shown in parenthesis, and standard errors robust to heteroscedasticity and serial correlation are shown in brackets. ${ }^{* * *}, * *$ and $*$ denote significance at the 1,5 and 10 percent level, respectively. Year and municipality-specific fixed effects are included in the estimations. The spatial weight matrix for computing neighbours' taxes is based on sharing border and is row standardized. The F-statistic is the test of excluded instruments obtained from the first-stage equation. Hansen $J$ is the p-value for the Hansen test of overidentifying restrictions. Instruments: neighbours' unemployment rate and neighbours' share of welfare recipients.

associated with a higher tax rate. ${ }^{2627}$ Intergovernmental grants are positively related to the tax rate. This relatively weak level of significance may be due to correlation between grants and tax base, since the grant equalization system equalizes the tax

\footnotetext{
${ }^{26}$ This result is anticipated if local public services are assumed to be income elastic. Note that average income (tax base) can be endogenously determined in the tax equation. This is presumably the case for a number of the included covariates (e.g., grants and the left-wing indicator), hence we should be careful in interpreting the effects as causal.

${ }^{27}$ It is worth noting that excluding tax base as a variable does not yield a tax interaction coefficient that is significantly different from the estimate in Table 2 (see Table A.2, Appendix).
} 
base across municipalities. ${ }^{28}$ Furthermore, as expected, the larger is the population in the municipality, the lower is the tax rate, possibly indicating economies of scale in the production of local public services. Eq. (9) accounts for the need for social assistance, by including both the rate of municipal unemployment and the share of individuals on welfare benefits. A larger share of unemployed gives rise to a higher local tax rate, while the share of welfare recipients is not related to the tax rate. According to column 2, the tax rate is not correlated with the party affiliation of the local government. Finally, capturing the cost of public goods provision, the share of young and old puts an upward pressure on the tax rate; the point estimates are positive and the share of elderly is significant at the 5 percent significance level.

We note that, although allowing for potential autocorrelation in the error process yields standard errors that are considerably higher than when computing heteroscedasticity consistent errors, the results are overall robust to the former, more restrictive estimator.

Turning to the validity of the instruments, standard tests of validity are reported in table 2. The F-statistic from the first-stage equation is above $10^{29}$, which is suggested as the critical value for explanatory power in Staiger and Stock (1997). Moreover, the Hansen test of over-identifying restrictions does not reject the validity of the instruments. Consequently, standard testing of the instruments suggests that the estimate of the spatial coefficient can be interpreted as a genuine or substantive interaction.

Furthermore, we make use of an additional test for instrument validity, namely an informal approach of the test proposed by Altonji et al. (2002, 2005). This test is based upon the idea that under certain conditions, the degree of selection on observables can provide a guideline as to how much selection there is in the unobservables. If the point estimate of the interaction parameter (i.e. the weighted average of neighbours' tax rates) is shown to be insensitive to the inclusion of additional covariates, the estimate would also be insensitive to the inclusion of additional unobservables. The test results from a stepwise expansion of covariates, are described in section A2, Appendix, and support the exogeneity of the instruments.

In addition to these tests of instrument validity, we have re-run the tax equation using different sets of instruments as a robustness check. We have laborated with a combination of the following instruments: neighbours' grants, neighbours' rate of unemployment and neighbours' share of welfare recipients, in the current period or lagged one time period. The results, that can be found in the Appendix, support our baseline finding.

\footnotetext{
${ }^{28}$ Excluding taxable income in the equation gives a stronger positive and significant effect of grants on the tax rate.

${ }^{29}$ The heteroscedasticity-robust F-statistic is 33.18 . We only report the the heteroscedastic- and autocorrelation-robust F-statistic in the following.
} 


\subsection{Alternative definitions of neighbourhood}

So far, interaction has been assumed to take place between adjacent municipalities. In the context of both tax and yardstick competition there may however be other relevant assumptions that can define the likelihood of interaction. In this section we will therefore, in addition to the border-sharing criterion, construct alternative neighbourhood definitions, based on the assumptions of the two interaction models. While this is not a clear test of the source of interaction, the pattern of the results from the different specifications, that to different degrees reflect the two theories, can still give us some guidance to the source of interaction.

Equation (9) is estimated using the following alternative weighting criteria $W$ :

Let $w_{i j}$ define the elements in the weight matrix $W$ (in equation $(9)$ ), then $w_{i j}$ describes the degree of proximity between $i$ and $j$, i.e, $w_{i j}$ is the weight that the neighbouring municipality $j$ has for municipality $i$.

First, we define neighbouring municipalities according to migration flows and construct a migration weight matrix where $w_{i j}=$ migration $_{i j}$ where migration $_{i j}=$ the average out-migration from $i$ to $j$, of individuals aged 16-65 in 1995-2002 and $w_{i j}=0$ otherwise ${ }^{30}$. This definition is closely related to the tax competition model which assumes that inter-municipal interaction is driven by competition for mobile tax payers.

Secondly, we want to account for the fact that information is an important aspect, in both theories of strategic tax interaction. In order to behave strategically, the decision-makers, as well as the voters or tax payers, need to be informed of the tax rates of the surrounding jurisdictions. To capture the degree of information between $i$ and $j$, we construct a media weight matrix; $w_{i j}=$ newspaper $_{i j}$ xcoverage $_{i j}$, where newspaper $_{i j}=1$ if $i$ and $j$ share a local newspaper, and coverage $_{i j}=$ the sum of average newspaper coverage of the local newspapers in $j$ and $w_{i j}=0$ otherwise ${ }^{3132}$.

Finally, we take into account the possibility that having similar preferences for locally provided services can facilitate comparisons of fiscal policies across municipalities. Citizens may base their voting, or moving decision, on comparisons of fiscal policies across municipalities with similar ideological positions. Hence, border-sharing neighbours are grouped according to their ideological stance, i. e, left- or right-wing.

\footnotetext{
${ }^{30}$ Data on migration was made available by The Institute for Labour Market Policy Evaluation, and is originally from Statistics Sweden. These data were generated in Edmark (2006).

${ }^{31}$ The data on local newspapers is from 1994, 1998 eller 2002 and is from Tidningsstatistik AB. We are grateful to Helena Svaleryd och Jonas Vlachos for having made it available to us.

${ }^{32}$ We select all newspapers that are given out at least six days a week. This leaves some municipalities with no newspaper. For these we include newspapers that are given out less then six days a week. There are two newspapers that have a national coverage, Dagens Nyheter and Svenska Dagbladet. These are counted as local newspapers only for the municipalities in the Stockholm county, since they cover local news in this region.
} 
More precisely, the tax rate of same majority refers to neighbours with the same majority party coalition as the incumbent coalition in municipality $i$; i.e. the spatial weight matrix is zero for all neighbours $j$ that belong to a party coalition $p \neq p_{i}$, whereas the tax rate from that of different majority refers to neighbours with a different party affiliation than the majority in the municipality. i.e. the spatial weight matrix is zero for all neighbours $j$ that belong to a party coalition $p=p_{i}{ }^{33}$

In addition to these neighbourhood definitions, we also construct a weight matrix based on an arbitrary neighbourhood criterion, namely being adjacent as we rank the municipalities in alphabetical order. ${ }^{3435}$ The idea is that by using this arbitrary measure of neighbourliness, we can test whether our interaction coefficient at all measures a spatial pattern, or whether we would obtain the same results irrespective of how we define neighbours. Naturally, we expect to find no tax interaction as we use the alfabetic weight matrix.

The results using alternative definitions of neighbourhood are displayed in Table 3, columns 2-5. For comparison, the baseline results using the border-sharing criterion are presented in column 1 .

Table 3: Alternative definitions of neighborhood

\begin{tabular}{|c|c|c|c|c|c|}
\hline & $\begin{array}{c}\text { WBorder } \\
(1)\end{array}$ & $\begin{array}{c}\text { WMigration } \\
(2)\end{array}$ & $\begin{array}{c}\text { WMedia } \\
(3)\end{array}$ & $\begin{array}{c}\text { WPolitics } \\
(4)\end{array}$ & $\begin{array}{c}\text { W Alphabetical } \\
\text { (5) }\end{array}$ \\
\hline \multirow[t]{3}{*}{ Tax rate of neighbours } & 0.794 & 0.374 & 0.949 & & 0.507 \\
\hline & $(0.247)^{* * *}$ & $(0.063)^{* * *}$ & $(0.138)^{* * *}$ & & $(0.395)$ \\
\hline & {$[0.207]^{* * *}$} & {$[0.106]^{* * *}$} & {$[0.262]^{* * *}$} & & {$[0.622]$} \\
\hline \multirow[t]{3}{*}{ Neighbours, same majority } & & & & 0.467 & \\
\hline & & & & $(0.153)^{* * *}$ & \\
\hline & & & & {$[0.295]$} & \\
\hline \multirow[t]{3}{*}{ Neighbours, different majority } & & & & 0.178 & \\
\hline & & & & $(0.110)$ & \\
\hline & & & & {$[0.201]$} & \\
\hline Controls & yes & yes & yes & yes & yes \\
\hline Year effects & yes & yes & yes & yes & yes \\
\hline Fixed effects & yes & yes & yes & yes & yes \\
\hline F-test & 10.97 & 21.11 & 22.87 & 2.73 & 2.92 \\
\hline F-test different & & & & 2.49 & \\
\hline Hansen J (p-value) & 0.483 & 0.541 & 0.240 & 0.437 & 0.902 \\
\hline Obs. & 3085 & 3085 & 3074 & 802 & 3085 \\
\hline
\end{tabular}

Note: The dependent variable is the municipal tax rate. Standard errors robust to heteroscedasticity are shown in parenthesis, and standard errors robust to heteroscedasticity and serial correlation are shown in brackets. ${ }^{* * *},{ }^{* *}$ and ${ }^{*}$ denote significance at the 1,5 and 10 percent level, respectively. Year and municipality-specific fixed effects are included in the estimations. For the construction of the spatial weight matrix for computing neighbours' taxes, col 2-5, see text. The F-statistic is the test of excluded instruments obtained from the first-stage equation. Hansen $\mathrm{J}$ is the p-value for the Hansen test of overidentifying restrictions. Instruments: neighbours' unemployment rate and neighbours' share of welfare recipients.

\footnotetext{
${ }^{33}$ Since only municipalities that have neighbours of both the same and different political majority are included in this specification, the sample size decreases to 802 observations.

${ }^{34}$ Specifically, we define the two preceding and the two following municipalities in alphabetical order as neighbours.

${ }^{35}$ This follows e.g. Case et. al. (1993).
} 
As can be seen in Table 3, the coefficient on neighbours' tax rate exhibits the same pattern as in the baseline specification. The estimate is positive and significant when defining neighbours using the migration criteria, as well as in the case with the media weight matrix. Defining municipalities as neighbours if the share a common media market, does however results in an interaction coefficient close to 1 , which is suspiciously high, since a coefficient above one is not compatible with a stable interaction process and this result should be interpreted with caution.

When grouping border-sharing neighbours according to their political affiliation, the estimates in column 4 suggest that interaction is taking place between municipalities with similar preferences, whereas the results show neighbours' tax rates in municipalities with a different ideological positition to have an insignificant effect on the own tax rate. This result does however not hold when we cluster the standard errors at the municipality level.

The result using the alphabetical weight matrix in column 5 finally confirms that our interaction coefficient is indeed picking up something spatial; the interaction coefficient is insignificant when we use the alphabetic definition of neighbours.

We interpret the results in Table 3 as broadly supporting the hypothesis of strategic interaction in the tax rate. Using different specifications that, in different ways, are based on the tax competition and yardstick competition theories, yields interaction coefficients that are significant, whereas our arbitrary alphabetic neighbourhood definition yields an insignificant result. The result of column 4 is furthermore in line with the hypothesis that interaction takes place between municipalities with similar political preferences. Overall, the results are robust to the more restrictive specification in which we allow the errors to be serially correlated within municipality.

The results in Table 3 can be interpreted as support for both the tax and the yardstick competition hypotheses, since significant interaction coefficients are obtained using neighbour definitions that are derived from either of the theories. For more thorough tests of strategic interaction, however, we turn to the next section.

\section{Identification of strategic tax interaction}

The results of the previous section indicate there to be a spatial pattern in the municipalities' tax rates. Our instrument tests have also given support for the validity of the instruments, which indicates that the source of the spatial pattern is some form of spatial interaction, and not merely due to spatial error correlation. Hence, we can conclude that the data shows evidence of spatial interaction in the tax rates of the municipalities.

In the above section we used the comparison of results from alternative definitions of neighbourhood as an indirect test of strategic interactions. In this section, we 
exploit empirical implications that are consistent with the tax competition and the yardstick competition framework, respectively, to provide a further test of strategic interaction. ${ }^{36}$ First, to test for tax competition, we use a reform of the equalization grants system which changed the incentives for local politicians to interact in the setting of municipal tax rates. Second, we make use of features of the electoral system to identify yardstick competition effects.

There are other studies which have been devoted to identifying the underlying behaviour of the spatial correlation in taxes by providing support for one of the hypotheses. Esteller-Moré and Solé-Ollé (2002) use a feature of the equalization grants system to test for tax competition in Canada ${ }^{37}$, and Besley and Case (1995), Bordignon et al. (2003) and Solé-Ollé (2003) test for yardstick competition using predictions regarding the electoral process. In this study, we recognize that these mechanisms are by no means mutually exclusive, but that they may well take place simultaneously. Therefore, we will attempt to test for both.

\subsection{Grant reform}

As previously discussed, when tax bases are mobile across regions, tax competition may have negative consequences for efficiency due to a race to the bottom in tax effort and hence, will put a downward pressure on local government spending. However, a system of equalizing grants can correct for this and lead to an efficient outcome, ${ }^{38}$ due to the fact that the negative effect of higher tax rates on the tax base is partly compensated by higher equalizing transfers.

Sweden is viewed as an highly ambitious country regarding horizontal equity in the distribution of public services. ${ }^{39}$ Similarly to a number of countries, Sweden has a system of tax revenue and expenditure equalization. The purpose of tax revenue equalization is to bring per capita tax revenues in all regions close to the national average. ${ }^{40}$

In the 1990s, the Swedish grant system underwent a reform, which changed the formula for the tax base equalization grants. We argue that this reform can be used to test for the presence of tax competition among Swedish municipalities. If local governments act strategically to attract mobile tax payers, they should react to a

\footnotetext{
${ }^{36}$ For a discussion regarding identification of the theoretical model in this context, see, e.g. Brueckner (2003) and Revelli (2005).

${ }^{37}$ They use the fact that in Canada, only provinces with a tax revenue below a certain level receive equalization grants, to test whether interaction is weaker among the receiving provinces, as suggested by the tax competition model. They find this to be the case, and conclude that the equalization grant mitigates horizontal tax competition.

${ }^{38}$ See e.g. Bucovetsky and Smart (2002) and Koethenbuerger (2002).

${ }^{39}$ See e.g. Rodden et al. (2003).

${ }^{40}$ The expenditure equalization aims at reducing the differences in structural cost conditions of public services across municipalities.
} 
reform that changes the system of tax revenue equalization among municipalities. ${ }^{41}$

The Swedish tax revenue equalizing grant is calculated on basis of the difference between country-wide average taxable income and average taxable income in the municipality. The effective grant received by a municipality is given by multiplying this difference by a factor of 0.95 , as well as by the average tax rate in the country and the number of inhabitants in the municipality. ${ }^{42}$ In Sweden, the grant hence compensates for $95 \%$ of the difference between the own tax base and the countryaverage.

In 1996, the equalization grants system was reformed. Prior to 1996, the municipalities were granted $127 \%$ of the country-wide average taxable income. Municipalities with a tax base exceeding $127 \%$ of the country-wide average, and hence ending up with a negative equalization grant according to the grants formula, were exempt from the system. ${ }^{43}$ This implies that all municipalities were given either positive or zero equalization grants.

The reform of 1996 changed two features of the equalizing grants system: first, the municipalities were granted $100 \%$, instead of $127 \%$, of the country-average of the tax base ${ }^{44}$ and second, the new system allowed for no exemptions, but encompassed all municipalities. Under the new system, a municipality hence paid a positive contribution (negative grant) to the system, if the average taxable income in the municipality exceeded the country-wide average and paid a negative contribution (received a positive grant) if it were below the country-wide average. The new system was thus neutral in the sense of its not being dependent on financing from the central government.

The new system made the tax base equalization clearer and more directly visible

\footnotetext{
${ }^{41}$ Specifically, if we consider the theoretical tax competition model described in section 2.2., it is easily shown that an increase in the degree of equalization of the municipal tax base is expected to decrease the level of tax competition. If we assume the tax base to be fully equalized among the municipalities, a municipality's effective tax base is no longer equal to that of its tax payers, $s_{i}$ in terms of the theoretical model, but instead to the average tax base of the country, $\bar{s}$. Inserting $\bar{s}$ in the place of $s_{i}$ in equation (3) of section 2.2, results in a tax equation where the tax rate of a municipality is no longer a direct function of the neighbouring municipalities' tax levels, but instead a direction function of the average tax base of the country; $\tau_{i}=\tau\left(\bar{s} ; X_{i}\right)$.

${ }^{42}$ The grants formula is: $G_{i}=0.95 n_{i} t\left((y g)-y_{i}\right)$, where $n_{i}$ is the number of inhabitants in municipality $i, t$ is the average tax rate in the country, $y$ is the country-wide average taxable income, $g$ is the guaranteed level from the central government and $y_{i}$ is the average taxable income in municipality $i$.
}

$$
G_{i}=0.95 n_{i} t y g-0.95 n_{i} t y_{i}
$$

shows that the equalization grant affected by the own tax base as a share of the total equalization grant increases as $g$ decreases.

${ }^{43}$ However, in practise, only three municipalities were affected by this: Danderyd, Täby and Lidingö.

${ }^{44}$ In terms of the grants formula of the previous note, $g$ changed from 1.27 to 1 . 
to the municipalities; first, by encompassing all municipalities and second, by making the system financially neutral where municipalities with good conditions directly compensate those with poorer conditions ${ }^{45}{ }^{46}$ We therefore expect it to affect tax competition in the same way as a direct increase in the tax base equalization would do; i.e. we expect the reform to decrease the prevalence of tax competition.

Before turning to the analysis, it might be asked whether the reform was substantial enough to have any real effect on the behaviour of the municipalities. There are a number of circumstances suggesting that the reform was in fact substantial. First, the reform gave rise to protests from municipalities that were financially harmed by the increased equalization, and has frequently been discussed in the public debate. Thus, it seems that the local policymakers experienced that the change in revenue equalization did have an effect on local revenues. Second, this debate has led to a partial reversal of the changes implemented in 1996. In 2001, a system of partial financial compensation was introduced for those municipalities which end up as netpayers (receiving negative grants), and in 2005 the guaranteed level of the tax base was increased from $100 \%$ to $115 \%$ of the country-wide average.

The hypothesis that the reform of the grants system gave rise to a decrease in the level of interactions in the tax rate between neighbouring municipalities is tested by re-estimating the tax reaction equation (9) including neighbours' tax rate interacted with a dummy variable to indicate the pre- and post-reform periods.

Table 4 displays the results. In columns 1 and 2, the tax rates of neighbours are interacted with a dummy, taking the value of 1 after the reform, and 0 otherwise. It is plausible that the reform also had an effect on the own tax rate and if neglected, this could affect the interaction estimate. In columns 3 and 4, the tax base and grants received in the own municipality are also interacted, thus allowing different impacts before and after the reform also in these variables.

If we look at the results in the first column of Table 4, the results indicate that interaction is about 0.1 lower after the reform. However this effect is only significant at the ten percent level when we estimate heteroscedasticity robust standard errors, and turns insignificant as we cluster on municipality. In addition, also allowing for taxable income and grants to have different impacts before and after the reform, shown in column 2, yields no evidence of lower interaction after the reform.

\footnotetext{
${ }^{45}$ As discussed in the Swedish Government Official Report, SOU 2000:120, this specific feature of the system introduced in 1996 dramatically changed the design of the equalization system, from being a more indirect system to more direct equalization.

${ }^{46}$ In addition, one can argue that the new system made equalization more visible to the individual municipality by increasing the relative weight of the share of the grant that depends on the municipality-specific tax base in the grants formula.
} 
Table 4: Pre- and postreform interactions 1993-2003

\begin{tabular}{|c|c|c|}
\hline & $(1)$ & $(2)$ \\
\hline \multirow[t]{2}{*}{ Neighbours' tax rate } & $\begin{array}{c}0.589 \\
(0.132) * * *\end{array}$ & $\begin{array}{c}0.764 \\
(0.162) * * *\end{array}$ \\
\hline & {$[0.215] * * *$} & {$[0.246] * * *$} \\
\hline \multirow[t]{2}{*}{ Neighbours' tax rate*Reform } & $\begin{array}{l}-0.083 \\
(0.046) *\end{array}$ & $\begin{array}{c}-0.001 \\
(0.084)\end{array}$ \\
\hline & {$[0.076]$} & {$[0.098]$} \\
\hline \multirow[t]{2}{*}{ Taxable income } & $\begin{array}{c}0.004 \\
(0.0007) * * *\end{array}$ & $\begin{array}{c}0.005 \\
(0.0007) * * *\end{array}$ \\
\hline & {$[0.001] * * *$} & {$[0.001] * * *$} \\
\hline \multirow[t]{2}{*}{ Grants } & $\begin{array}{c}0.00002 \\
(1.00 \mathrm{e}-05)\end{array}$ & $\begin{array}{l}0.00003 \\
(0.00002)\end{array}$ \\
\hline & {$[0.00002]$} & {$[0.00002]$} \\
\hline \multirow[t]{2}{*}{ Unemployment rate } & $\begin{array}{c}0.029 \\
(0.012) * *\end{array}$ & $\begin{array}{c}0.025 \\
(0.012) * *\end{array}$ \\
\hline & {$[0.021]$} & {$[0.019]$} \\
\hline \multirow[t]{2}{*}{ Population size } & $\begin{array}{c}-0.102 \\
(0.03) * * *\end{array}$ & $\begin{array}{c}-0.095 \\
(0.029) * * *\end{array}$ \\
\hline & {$[0.072]$} & {$[0.069]$} \\
\hline \multirow[t]{2}{*}{ Proportion of young (0-15) } & $\begin{array}{c}8.55 \mathrm{e}-06 \\
(0.041)\end{array}$ & $\begin{array}{l}0.045 \\
(0.039)\end{array}$ \\
\hline & {$[0.079]$} & {$[0.072]$} \\
\hline \multirow[t]{2}{*}{ Proportion of elderly $(65+)$} & $\begin{array}{c}0.102 \\
(0.025) * * *\end{array}$ & $\begin{array}{c}0.135 \\
(0.028) * * *\end{array}$ \\
\hline & {$[0.042] * *$} & {$[0.05] * * *$} \\
\hline \multirow[t]{2}{*}{ Share of welfare recipients } & $\begin{array}{l}0.003 \\
(0.014)\end{array}$ & $\begin{array}{l}0.008 \\
(0.013)\end{array}$ \\
\hline & {$[0.023]$} & {$[0.023]$} \\
\hline \multirow[t]{2}{*}{ Left-wing } & $\begin{array}{c}-0.039 \\
(0.03)\end{array}$ & $\begin{array}{c}-0.049 \\
(0.032)\end{array}$ \\
\hline & {$[0.032]$} & {$[0.032]$} \\
\hline Taxable income*Reform & & $\begin{array}{c}-0.0005 \\
(0.0003) * * \\
{[0.0004]}\end{array}$ \\
\hline \multirow[t]{2}{*}{ Grants*Reform } & & $\begin{array}{c}-1.00 \mathrm{e}-05 \\
(1.00 \mathrm{e}-05)\end{array}$ \\
\hline & & {$[0.00002]$} \\
\hline Year effects & yes & yes \\
\hline Fixed effects & yes & yes \\
\hline F-test & 10.98 & 15.08 \\
\hline F-test Reform & 32.48 & 21.13 \\
\hline Hansen J (p-value) & 0.157 & 0.155 \\
\hline Obs. & 3085 & 3085 \\
\hline
\end{tabular}

Note: The dependent variable is the municipal tax rate. Standard errors robust to heteroscedasticity are shown in parenthesis, and standard errors robust to heteroscedasticity and serial correlation are shown in brackets. $* * *, * *$ and $*$ denote significance at the 1,5 and 10 percent level, respectively. Year and municipality-specific fixed effects are included in the estimations. The spatial weight matrix for computing neighbours' taxes is based on sharing border and is row standardized. The F-statistic is the test of excluded instruments obtained from the first-stage equation. Hansen $\mathrm{J}$ is the p-value for the Hansen test of overidentifying restrictions. Instruments: neighbours' unemployment rate and neighbours' share of welfare recipients. 
The coefficient of neighbours' tax rate is positive and significant as in the baseline case. It is notable, however, that the coefficient of the specification in column 1 is lower than what we would expect considering the estimate of the baseline regression in Table 2. A possible explanation for this is that some of the interaction effect is picked up by the year effects for the pre-reform period.

The results of Table 4 give no, or weak, evidence of a decrease in tax interaction after the grants reform. ${ }^{47}$

\subsection{Testing for yardstick competition effects}

In this section, we will make use of two general predictions from yardstick competition theory. ${ }^{48}$ First, there is the prediction that confident of re-election, incumbents facing certain electoral outcomes can implement their own preferred fiscal policies irrespective of neighbours' policies. The yardstick theory is hence consistent with the prediction that in municipalities where the ruling coalition is weak, a small deviation from neighbours' tax rate (given $X_{i}$ ) may have a high effect on the probability of winning the election, while in municipalities where the majority is large, there is more leeway in deviating. ${ }^{49}$ Hence, we expect tax rate interaction to be stronger in municipalities where the ruling majority is weak. Moreover, the opportunistic behaviour of politicians is expected to be stronger in election years. If voters compare fiscal performance according to eq. (7), politicians will have stronger incentives to set taxes in line with the tax policy in neighbouring regions, in connection with the local election. Hence, we expect the interaction in tax setting to be stronger during election years. ${ }^{50}$ Table 5 displays the results.

\footnotetext{
${ }^{47}$ It could also be argued that a clearer equalization of the tax base has an effect on the prevalence of yardstick competition behaviour. The idea in this case is that equalization increases the voters' information set. Equalization of the tax base means that the economic resources available to the politicians of the jurisdictions become more similar and hence, cannot be blamed for differences in service provision across jurisdictions. Accordingly, equalization would lead to more yardstick competition and hence, more interaction.

${ }^{48}$ Similar tests for yardstick competition effects are used in e.g. Besley and Case (1995), Bordignon et al. (2003) and Solé-Ollé (2003).

${ }^{49}$ As described in section 2.2 , the yardstick competition theory models a situation where the objective of the tax setter, the incumbent, is to maximize personal rents, but where the rent-seeking behavior is restricted by the electoral process. An incumbent who extracts rents (or more correctly, according to the model, extracts more rents than her neighbours), which is reflected in higher taxes for a given level of service, will face a lower probability of re-election. As a result, the probability of re-election is not only affected by the own tax rate, but also by that of nearby jurisdictions (see equation $(7))$.

${ }^{50} \mathrm{In}$ models of rational election cycles, the prediction is that politicians signal their competence by reducing taxes (and increasing spending) in election years, see e.g. Persson and Tabellini (2000). The election dummy may pick up both the effect of lower taxes in election years and stronger incentives to interact in the tax setting, both due to stronger incentives to perform just ahead of elections. However, to the extent that the former effect is similar for all municipalities, it will be controlled for by the inclusion of year-specific effects.
} 
Table 5: Electoral tightness and election year

\begin{tabular}{|c|c|c|c|}
\hline & $\begin{array}{c}\text { Weak } \\
(1)\end{array}$ & $\begin{array}{c}\text { Weak } \\
(2)\end{array}$ & $\begin{array}{c}\text { Election year } \\
(3)\end{array}$ \\
\hline \multirow[t]{2}{*}{ Neighbours' tax rate } & $\begin{array}{c}0.792 \\
(0.133) * * *\end{array}$ & $\begin{array}{c}0.654 \\
(0.138) * * *\end{array}$ & $\begin{array}{c}0.782 \\
(0.122) * * *\end{array}$ \\
\hline & {$[0.209] * * *$} & {$[0.246] * * *$} & {$[0.192] * * *$} \\
\hline \multirow[t]{2}{*}{ Neighbours' tax*Weak } & $\begin{array}{c}-0.0006 \\
(0.002)\end{array}$ & $\begin{array}{c}0.136 \\
(0.048) * * *\end{array}$ & \\
\hline & {$[0.003]$} & {$[0.11]$} & \\
\hline \multirow[t]{2}{*}{ Neighbours' tax*Election } & & & $\begin{array}{l}0.003 \\
(0.033)\end{array}$ \\
\hline & & & {$[0.021]$} \\
\hline \multirow[t]{2}{*}{ Taxable income } & $\begin{array}{c}0.005 \\
(0.0007) * * *\end{array}$ & $\begin{array}{c}0.005 \\
(0.0007) * * *\end{array}$ & $\begin{array}{c}0.005 \\
(0.0007) * * *\end{array}$ \\
\hline & {$[0.001] * * *$} & {$[0.001] * * *$} & {$[0.001] * * *$} \\
\hline \multirow[t]{2}{*}{ Grants } & $\begin{array}{c}0.00002 \\
(1.00 \mathrm{e}-05) *\end{array}$ & $\begin{array}{c}0.00002 \\
(1.00 \mathrm{e}-05) *\end{array}$ & $\begin{array}{c}0.00002 \\
(1.00 \mathrm{e}-05) *\end{array}$ \\
\hline & {$[0.00002]$} & {$[0.00002]$} & {$[0.00002]$} \\
\hline \multirow[t]{2}{*}{ Unemployment rate } & $\begin{array}{c}0.022 \\
(0.012) *\end{array}$ & $\begin{array}{c}0.023 \\
(0.013) *\end{array}$ & $\begin{array}{c}0.023 \\
(0.012) *\end{array}$ \\
\hline & {$[0.02]$} & {$[0.021]$} & {$[0.02]$} \\
\hline \multirow[t]{2}{*}{ Population size } & $\begin{array}{c}-0.095 \\
(0.028) * * *\end{array}$ & $\begin{array}{c}-0.099 \\
(0.029) * * *\end{array}$ & $\begin{array}{c}-0.096 \\
(0.028) * * *\end{array}$ \\
\hline & {$[0.067]$} & {$[0.069]$} & {$[0.068]$} \\
\hline \multirow[t]{2}{*}{ Proportion of young (0-15) } & $\begin{array}{c}0.05 \\
(0.034)\end{array}$ & $\begin{array}{l}0.037 \\
(0.035)\end{array}$ & $\begin{array}{l}0.049 \\
(0.033)\end{array}$ \\
\hline & {$[0.07]$} & {$[0.072]$} & {$[0.069]$} \\
\hline \multirow[t]{2}{*}{ Proportion of elderly $(65+)$} & $\begin{array}{c}0.133 \\
(0.028) * * *\end{array}$ & $\begin{array}{c}0.125 \\
(0.027) * * *\end{array}$ & $\begin{array}{c}0.131 \\
(0.027) * * *\end{array}$ \\
\hline & {$[0.053] * *$} & {$[0.051] * *$} & {$[0.05] * * *$} \\
\hline \multirow[t]{2}{*}{ Share of welfare recipients } & $\begin{array}{l}0.007 \\
(0.014)\end{array}$ & $\begin{array}{l}0.007 \\
(0.013)\end{array}$ & $\begin{array}{l}0.006 \\
(0.013)\end{array}$ \\
\hline & {$[0.024]$} & {$[0.022]$} & {$[0.023]$} \\
\hline \multirow[t]{2}{*}{ Left-wing } & $\begin{array}{l}-0.051 \\
(0.033)\end{array}$ & $\begin{array}{l}-0.03 \\
(0.032)\end{array}$ & $\begin{array}{c}-0.046 \\
(0.031)\end{array}$ \\
\hline & {$[0.038]$} & {$[0.034]$} & {$[0.032]$} \\
\hline \multirow[t]{2}{*}{ Weak Majority } & & $\begin{array}{c}-2.772 \\
(0.983) * * *\end{array}$ & \\
\hline & & {$[2.258]$} & \\
\hline Year effects & yes & yes & yes \\
\hline Fixed effects & yes & yes & yes \\
\hline F-test & 8.00 & 8.02 & 20.51 \\
\hline F-test Weak & 756.14 & 46.99 & \\
\hline F-test Election year & & & 37.86 \\
\hline Hansen J (p-value) & 0.7542 & 0.646 & 0.350 \\
\hline Obs. & 3085 & 3085 & 3085 \\
\hline
\end{tabular}

Note: The dependent variable is the municipal tax rate. Standard errors robust to heteroscedasticity are shown in parenthesis, and standard errors robust to heteroscedasticity and serial correlation are shown in brackets. ${ }^{* * *},{ }^{* *}$ and ${ }^{*}$ denote significance at the 1,5 and 10 percent level, respectively. Year and municipality-specific fixed effects are included in the estimations. The spatial weight matrix for computing neighbours' taxes is based on sharing border and is row standardized. The F-statistic is the test of excluded instruments obtained from the first-stage equation. Hansen $\mathrm{J}$ is the p-value for the Hansen test of overidentifying restrictions. Instruments: neighbours' unemployment rate and neighbours' share of welfare recipients. 
In column 1 , the tax rate of neighbours is interacted with a dummy taking on the value of one if the political majority of the municipality is weak, and zero otherwise. ${ }^{51}$ The result from this specification does not indicate any difference in interaction between municipalities with a weak and strong political majority; the coefficient for neighbours' tax interacted with our indicator for a weak majority is insignificant. However, it may well be that having a weak political majority has an independent effect on the tax rate. ${ }^{52}$ The result from this specification, using heteroscedasticity robust standard errors, indicates tax interaction to be stronger in municipalities where the political majority is weak, i.e. politicians tend to react more to neighbours' tax rates when facing a tight electoral race. The coefficient states that the tax interaction is 0.14 higher when the political majority is weak, which is a substantial difference. This pattern - a negative effect on the tax rate of having a weak majority, and a stronger tax-interaction in municipalities with a weak majority - is consistent with the findings of Solé-Ollé (2003). ${ }^{53}$ However, clustering on municipality, the coefficient turns insignificant.

Column 3 displays the results when interacting neighbours' tax rate with an election year dummy. ${ }^{54}$ The result does not support the prediction that strategic interaction is stronger during election years. However, this result may be due to little variation, considering that there are only three election years in our sample period.

To summarize, our results indicate positive spatial interactions to be present in Swedish municipalities. However, we find no, or weak, evidence that tax competition and yardstick competition contribute to these interactions.

\footnotetext{
${ }^{51}$ We define "weak" as a municipality, where either the left-wing or the right-wing block has a support equal to or less than 55 percent of the votes. According to this definition, in our sample of 3113 observations, there are 1752 municipalities where the majority is weak.

${ }^{52}$ This result is consistent with earlier work analysing the relationship between political competition and policy outcomes. For example, recent work by Besley and Case (2003) and Besley et al. (2005) find that increased political competition leads to lower taxes. However, according to our definition, municipalities with a weak majority include undefined party coalitions, where neither the left- nor the right-wing bloc is in power, which is typically the case when there are strong local parties. The indicator variable for weak majorities may hence pick up information on these local parties. Since we lack information on the party affiliation of local parties, we refrain from further interpreting this result.

${ }^{53}$ Bordignon et al. (2003) also present evidence supporting that incumbents facing uncertain electoral outcomes (i.e. not supported by large majorities) tend to react to neighbouring jurisdictions tax rates, whereas incumbents confident of reelection do not.

${ }^{54}$ There are three election years in our sample period: 1994, 1998 and 2002.
} 


\section{Conclusions}

This paper uses data on Swedish local governments to test for strategic interaction in municipal tax setting. Following a number of previous studies, the endogeneity of neighbouring local governments' taxes is handled using an IV approach where neighbours' tax rates are instrumented using a subset of neighbours' characteristics. Using an IV approach is intuitively appealing in this context, since identification becomes explicit; spatial interaction in taxes is caused by the changes in the part of neighbours' taxes attributable to the observable characteristics of neighbours, which are used as instruments.

We find evidence of positive spatial auto-correlation in tax rates: a tax cut of on average 1 percentage point in neighbouring jurisdictions leads to a decrease of about 0.79 percentage points in own taxes.

The result is robust to using different specifications of neighbourhood, that are derived from the tax competition and yardstick competition theories respectively. This suggests that there is a spatial pattern in the data that is consistent with the predictions from these theories.

However, we stress that to identify the source of the interaction, additional testing is needed. We therefore employ two tests based on empirical implications that are consistent with either the tax competition or the yardstick competition framework, to test for the source of interaction. First, to test for tax competition, we use a reform of the equalization grants system which changed the incentives for local politicians to interact in the setting of municipal tax rates. Second, we make use of features of the electoral system to identify yardstick competition effects.

Using these tests, the paper finds no (when accounting for dynamics by clustering on municipality), or weak (when not clustering) evidence supporting that the spatial auto-correlation in taxes among Swedish local governments can be explained by electoral concerns or incentives to attract mobile taxpayers, as suggested by the theories on strategic tax interaction.

Our results hence underline the importance of using direct tests for strategic interactions, in addition to estimating the spatial interaction equation. They also suggest that accounting for dynamics have potentially important effects. 


\section{References}

Alesina, A., Roubini, N. and Cohen, G.: 1997, Political Cycles and the Macroeconomy, MIT Press, Cambridge.

Allers, M. and Elhorst, J.: 2005, Tax mimicking and yardstick competition among local governments in the netherlands, International Tax and Public Finance 12, 493-513.

Altonji, J. G., Elder, T. E. and Taber, C. R.: 2002, An Evaluation of Instrumental Variable Strategies for Estimating the Effects of Catholic Schools, NBER Working Paper 9358.

Altonji, J. G., Elder, T. E. and Taber, C. R.: 2005, Selection on Observed and Unobserved: Assessing the Effectiveness of Catholic Schools, Journal of Political Economy 113, 151-184.

Anselin, L.: 1988, Spatial Econometrics: Methods and Models, Kluwer Academic Publishing, Dordrecht.

Bertrand, M., Duflo, E. and Mullainathan, S.: 2004, How much should we trust difference-in-difference estimates, Quarterly Journal of Economics 119, 249-275.

Besley, T. and Case, A.: 1995, Incumbent Behavior: Vote-Seeking, Tax-Setting, and Yardstick Competition, The American Economic Review 85, 25-45.

Besley, T. and Case, A.: 2003, Political institutions and policy choices: Evidence from the united states, Journal of Economic Literature 41(1), 7-73.

Besley, T., Persson, T. and Sturm, D.: 2005, Political competition and economic performance: Theory and evidence from the united states, Mimeo, Institute for International Economic Studies, Stockholm University .

Bordignon, M., Cerniglia, F. and Revelli, F.: 2003, In Search of Yardstick Competition: A Spatial Analysis of Italian Municipality Property Tax Setting, Journal of Urban Economics 54, 199-217.

Bordignon, M., Cerniglia, F. and Revelli, F.: 2004, Yardstick competition in intergovernmental relationships: Theory and empirical predictions, Economics Letters (83), 325-333.

Brett, C. and Pinkse, J.: 2000, The Determinants of Municipal Tax Rates in British Colombia, Canadian Journal of Economics 33, 695-714.

Brueckner, J. K.: 2003, Strategic Interaction Among Governments: An Overview of Empirical Studies, International Regional Science Review (26), 175-188. 
Brueckner, J. K. and Saavedra, L.: 2001, Do Local Governments Engage in Strategic Property-Tax Competition?, National Tax Journal 54, 203-229.

Bucovetsky, S. and Smart, M.: 2002, The Efficiency Consequences of Local Revenue Equalization: Tax Competition and Tax Distortions, CESIFO Working Paper 767.

Buettner, T.: 2001, Local business taxation and competition for capital: The choice of tax rate, Regional Science and Urban Economics 31, 215-245.

Case, A., Hines, J. R. and Rosen, H. S.: 1993, Budget Spillovers and Fiscal Policy Interdependence, Journal of Public Economics 52, 285-307.

Cliff, A. and Ord, J.: 1981, Spatial Processes. Models and Applications, Pion, London.

Dahlberg, M. and Edmark, K.: 2004, Is there a "Race-to-the-Bottom" in the Setting of Welfare Benefit Levels? Evidence from a Policy Intervention., Working Paper 2004:19, Department of Economics, Uppsala University .

Edmark, K.: 2006, Spatial interactions in public expenditures - evidence from swedish municipalities, mimeo, Department of Economics, Uppsala University .

Esteller-Moré, A. and Solé-Ollé, A.: 2002, Tax Setting in a Federal System: The Case of Personal Income Taxation in Canada, International Tax and Public Finance 9, 235-257.

Heyndels, B. and Vuchelen, J.: 1998, Tax mimicking among Belgian municipalities, National Tax Journal 51, 89-101.

Keleijan, H. and Robinson, D.: 1993, A Suggested Method of Estimation for Spatial Interdependent Models with Auto-Correlated Errors, and an Application to a Country Expenditure Model, Papers in Regional Science 72, 297-312.

Kelejian, H. and Prucha, I.: 1998, A generalized spatial two-stage least squares procedure for estimating a spatial autoregressive model with autoregressive disturbances, Journal of Real Estate Finance and Economics 17, 99-121.

Kézdi, G.: 2002, Robust standard errors estimation in fixed-effects panel models, mimeo, University of Michigan .

Köthenburger, M.: 2002, Tax Competition and Fiscal Equalization, International Tax and Public Finance 9, 391-408.

Mofitt, R.: 2001, Policy Interventions, Low-Level Equilibria and Social Interactions. in E. Durlauf and P. Young (eds.), Social Dynamics, MIT Press, 45-82. 
Oates, W.: 2002, Fiscal and regulatory competition: Theory and evidence, Perspektiven der Wirtschaftspolitik (3), 377-390.

Persson, T. and Tabellini, G.: 2000, Political Economics: Explaining Economic Policy, MIT Press, Cambridge.

Pettersson-Lidbom, P.: 2003, Do parties matter for policy choices? a regressiondiscontinuity approach, Working Paper 2003:15, Department of Economics, Stockholm University .

Revelli, F.: 2001, Spatial Patterns in Local Taxation: Tax Mimicking or Error Mimicking, Applied Economics 33, 1101-1107.

Revelli, F.: 2005, Spatial Interactions Among Governments. in E. Ahmad and G. Brosio (eds.), Handbook of Fiscal Federalism. Cheltenham: Edward Elgar (forthcoming).

Rodden, J. and Eskeland, G.: 2003, Introduction and Overview. in J Rodden and G Eskeland and J Litvack (eds.), Fiscal Decentralization and the Challenge of Hard Budget Contraints.

Solé-Ollé, A.: 2003, Electoral Accountability and Tax Mimicking: The Effects of Electoral Margins, Coalition Government, and Ideology, European Journal of Political Economy 19, 685-713.

SOU 2000:120, Förenklad Kommunal Utjämning: 2000.

Staiger, D. and Stock, J. H.: 1997, Instrumental Variables Regression with Weak Instruments, Econometrica 65(3), 557-586.

Wilson, J.: 1999, Theories of tax competition, National Tax Journal 52, 269-304. 


\section{A Appendix}

\section{A.1 Moran I test of a spatial pattern in the data}

The Moran I-statistic is based on measuring the covariance in the tax rates of neighbouring municipalities, relative to the variance in tax rates across all municipalities. ${ }^{55}$ Inference is carried out by calculating the Z-value of the test statistic and testing this against the null hypothesis of tax rates following the normal distribution. Applying Moran's I directly to the tax rates gives us an indication of whether there is a spatial pattern in the tax rate $t$, when no other factors are taken into account.

We are also interested in whether a spatial pattern is present when other factors included in our tax rate specification are controlled for. In this case, we first run the regression equation (9), but exclude the tax interaction term $\theta W \tau$. Then, we apply the Moran test to the predicted residuals. The idea is that if we find a spatial pattern to be present also when municipality-specific covariates are controlled for, this indicates that some spatially correlated variable has been omitted from the model. ${ }^{56}$

The tests are run using the border-based definition of neighbourhood, i.e. municipalities are defined as neighbours if they share border.

We ignore the time dimension of our data and perform the tests on the pooled cross-sections, and we test for a spatial pattern both in the tax levels and the deviations from the municipality-specific mean over the time period. The results are given in Table A.1. Columns 2 and 3 show the results for the Moran I-statistic when testing for a spatial process in the tax rate and the error term, respectively. The table shows the $Z$-values of the tests.

Table A.1: Diagnostic tests for spatial dependence

\begin{tabular}{lll}
\hline \hline & Moran I $(t)$ & Moran I $(e)$ \\
\hline Pooled OLS / level & 55.03 & -13.94 \\
& $(0.00)$ & $(0.00)$ \\
Pooled OLS / dev from mean & 56.78 & -9.24 \\
& $(0.00)$ & $(0.00)$ \\
\hline
\end{tabular}

Note: p-values are shown in parenthesis.

\footnotetext{
${ }^{55}$ The formula is shown in equation (11), where $\mathrm{N}$ denotes the number of observations, $w_{i j}$ is an indicator variable equal to one if municipality $i$ and $j$ are defined as neighbours, and zero otherwise. $t$ is the tax rate and $\bar{t}$ its mean

$$
\operatorname{Moran} I(t)=\frac{N}{\sum_{i} \sum_{j} w_{i, j}} \cdot \frac{\sum_{i, j=1}^{N} w_{i, j}\left(t_{i}-\bar{t}\right)\left(t_{j}-\bar{t}\right)}{\sum_{i=1}^{N}\left(t_{i}-\bar{t}\right)^{2}}
$$

${ }^{56} \mathrm{~A}$ drawback with the Moran I-statistic is, however, that it is not robust to misspecification in the spatial error process when testing for interaction in the dependent variable, and vice versa. Here, however, we merely want an indication of whether a spatial analysis of the data is motivated. The instrumental variable regressions will then tell us whether the indicated spatial pattern stems from interaction in our dependent variable.
} 
As shown in Table A.1, the null hypothesis of no spatial pattern is rejected for the tax rate as well as for the error term, and the test statistics are similar for the pooled OLS/tax level case and the deviations from the mean case.

\section{A.2 Specification test}

This section presents the results of an informal type of test of instrument validity proposed by Altonji et al. (2002, 2005). This test is based upon the idea that under certain conditions, the degree of selection on observables can provide a guideline as to how much selection there is in the unobservables. ${ }^{57}$.In our setting, this means that the observables in the tax reaction equation should be chosen so that there is no relationship between the instruments and the unobservables that determine the local tax rate. If the point estimate of the interaction parameter (i.e. the weighted average of neighbours' tax rates) is shown to be insensitive to the inclusion of additional covariates, the estimate would also be insensitive to the inclusion of additional unobservables.

First, we include the same set of controls as those used to instrument neighbours' tax rates (the rate of municipal unemployment and the share of welfare recipients). Second, we include the whole set of covariates except fixed unobserved municipalityspecific effects and third, we also account for unobservables by adding time invariant municipality-specific effects to the specification. The results of these specifications are presented in columns 1-3 in Table A.2.

Columns 1-3 give the regression estimates when using different subsets of own covariates. The point estimate of neighbours' tax rates when including the entire set of controls, displayed in column 2, decreases somewhat as compared to column 1 , where we control for the share of welfare recipients and the rate of unemployment, and increases somewhat, compared to column 1, when controlling for time-invariant unobservables by including municipality-specific fixed effects (column 3). However, all specifications basically yield similar results, i.e. the interaction coefficient is positive and significant and about the same size in all specifications. Hence, we interpret this as support for the validity of our instruments.

\footnotetext{
${ }^{57}$ The following conditions must hold for this to be the case: the subset of controls must be randomly chosen from the full set of observables, the number of covariates must be large, and none of the covariates should alone dominate the distribution of the outcome variable and the relationship between the observable elements and the unobservable elements must obey an assumption similiar to the standard assumption $\operatorname{Cov}(X \epsilon)=0$. See Altonji et al. (2002 and 2005) for details.
} 
Table A.2: Specification test

\begin{tabular}{|c|c|c|c|}
\hline & (1) & $(2)$ & $(3)$ \\
\hline \multirow[t]{2}{*}{ Neighbours' tax rate } & $\begin{array}{c}0.66 \\
(0.06) * * *\end{array}$ & $\begin{array}{c}0.528 \\
(0.062) * * *\end{array}$ & $\begin{array}{c}0.794 \\
(0.134) * * *\end{array}$ \\
\hline & {$[0.142] * * *$} & {$[0.146] * * *$} & {$[0.207] * * *$} \\
\hline \multirow[t]{2}{*}{ Taxable income } & & $\begin{array}{c}-0.001 \\
(0.0002) * * *\end{array}$ & $\begin{array}{c}0.005 \\
(0.0007) * * *\end{array}$ \\
\hline & & {$[0.0005] * *$} & {$[0.001] * * *$} \\
\hline \multirow[t]{2}{*}{ Grants } & & $\begin{array}{c}0.00004 \\
(7.55 \mathrm{e}-06) * * *\end{array}$ & $\begin{array}{c}0.00002 \\
(1.00 \mathrm{e}-05) *\end{array}$ \\
\hline & & {$[0.00002] * *$} & {$[0.00002]$} \\
\hline \multirow[t]{2}{*}{ Unemployment rate } & $\begin{array}{c}0.168 \\
(0.026) * * *\end{array}$ & $\begin{array}{c}0.101 \\
(0.021) * * *\end{array}$ & $\begin{array}{c}0.022 \\
(0.012) *\end{array}$ \\
\hline & {$[0.06] * * *$} & {$[0.049] * *$} & {$[0.019]$} \\
\hline \multirow[t]{2}{*}{ Population size } & & $\begin{array}{c}0.003 \\
(0.001) * *\end{array}$ & $\begin{array}{c}-0.095 \\
(0.028) * * *\end{array}$ \\
\hline & & {$[0.004]$} & {$[0.067]$} \\
\hline \multirow[t]{2}{*}{ Proportion of young (0-15) } & & $\begin{array}{l}0.003 \\
(0.016)\end{array}$ & $\begin{array}{c}0.05 \\
(0.034)\end{array}$ \\
\hline & & {$[0.04]$} & {$[0.07]$} \\
\hline \multirow[t]{2}{*}{ Proportion of elderly $(65+)$} & & $\begin{array}{c}0.031 \\
(0.01) * * *\end{array}$ & $\begin{array}{c}0.133 \\
(0.028) * * *\end{array}$ \\
\hline & & {$[0.024]$} & {$[0.053] * *$} \\
\hline \multirow[t]{2}{*}{ Share of welfare recipients } & $\begin{array}{c}0.135 \\
(0.017) * * *\end{array}$ & $\begin{array}{c}0.1 \\
(0.014) * * *\end{array}$ & $\begin{array}{l}0.007 \\
(0.014)\end{array}$ \\
\hline & {$[0.04] * * *$} & {$[0.031] * * *$} & {$[0.023]$} \\
\hline \multirow[t]{2}{*}{ Left-wing } & & $\begin{array}{c}0.183 \\
(0.042) * * *\end{array}$ & $\begin{array}{c}-0.046 \\
(0.031)\end{array}$ \\
\hline & & {$[0.099] *$} & {$[0.032]$} \\
\hline Year effects & yes & yes & yes \\
\hline Fixed effects & no & no & yes \\
\hline F-test & 46.44 & 29.45 & 11.97 \\
\hline Hansen J (p-value) & 0.000 & 0.006 & 0.483 \\
\hline Obs. & 3098 & 3085 & 3085 \\
\hline
\end{tabular}

Note: The dependent variable is the municipal tax rate. Standard errors robust to heteroscedasticity are shown in parenthesis, and standard errors robust to heteroscedasticity and serial correlation are shown in brackets. ${ }^{* *}, * *$ and $*$ denote significance at the 1,5 and 10 percent level, respectively. Year and municipality-specific fixed effects are included in the estimations. The spatial weight matrix for computing neighbours' taxes is based on sharing border and is row standardized. Instruments: neighbours' unemployment rate and neighbours' share of welfare recipients.

Comparing the results in column 2 with our baseline specification in column 3 , we can also note that when excluding municipality-specific fixed effects, a larger proportion of the population on welfare is positively related to the tax rate. Furthermore, the results indicate a positive correlation between taxes and left-wing majorities. This is in line with previous work on Swedish local governments. Pettersson-Lidbom (2003) finds evidence of a party effect on tax and spending policy: on average, left-wing governments spend and tax 2.5 percent more than right-wing governments. Moreover, the result suggests that the municipality-specific fixed effects, included in the baseline specification, effectively account for time-invariant unobservable characteristics, such as local preferences. 


\section{A.3 Vertical interactions}

Table A.3: Baseline estimation of the tax reaction function including county taxes

\begin{tabular}{|c|c|}
\hline & IV \\
\hline \multirow[t]{2}{*}{ Neighbours' tax rate } & $\begin{array}{c}0.718 \\
(0.168) * * *\end{array}$ \\
\hline & {$[0.255] * * *$} \\
\hline \multirow[t]{2}{*}{ Taxable income } & $\begin{array}{c}0.005 \\
0.0007) * * *\end{array}$ \\
\hline & {$[0.002] * * *$} \\
\hline \multirow[t]{2}{*}{ Grants } & $\begin{array}{c}0.00003 \\
(1.00 \mathrm{e}-05) * *\end{array}$ \\
\hline & {$[0.00002]$} \\
\hline \multirow[t]{2}{*}{ Unemployment rate } & $\begin{array}{c}0.023 \\
(0.012) *\end{array}$ \\
\hline & {$[0.020]$} \\
\hline \multirow[t]{2}{*}{ Population size } & $\begin{array}{c}-0.097 \\
(0.028) * * *\end{array}$ \\
\hline & {$[0.067]$} \\
\hline \multirow[t]{2}{*}{ Proportion of young (0-15) } & $\begin{array}{l}0.041 \\
(0.037)\end{array}$ \\
\hline & {$[0.075]$} \\
\hline \multirow[t]{2}{*}{ Proportion of elderly $(65+)$} & $\begin{array}{c}0.121 \\
(0.030) * * *\end{array}$ \\
\hline & {$[0.052] * *$} \\
\hline \multirow[t]{2}{*}{ Share of welfare recipients } & $\begin{array}{l}0.007 \\
(0.013)\end{array}$ \\
\hline & {$[0.023]$} \\
\hline \multirow[t]{2}{*}{ Left-wing } & $\begin{array}{c}-0.042 \\
(0.031)\end{array}$ \\
\hline & {$[0.032]$} \\
\hline \multirow[t]{2}{*}{ County tax rate } & $\begin{array}{c}-0.060 \\
(0.040)\end{array}$ \\
\hline & {$[0.071]$} \\
\hline F-test & 9.59 \\
\hline Hansen J (p-value) & 0.492 \\
\hline Obs. & 3085 \\
\hline
\end{tabular}

Note: The dependent variable is the municipal tax rate. Standard errors robust to heteroscedasticity are shown in parenthesis, and standard errors robust to heteroscedasticity and serial correlation are shown in brackets. ${ }^{* * *},{ }^{* *}$ and ${ }^{*}$ denote significance at the 1,5 and 10 percent level, respectively. Year and municipality-specific fixed effects are included in the estimations. The spatial weight matrix for computing neighbours' taxes is based on sharing border and is row standardized. The F-statistic is the test of excluded instruments obtained from the first-stage equation. Hansen $J$ is the p-value for the Hansen test of overidentifying restrictions. Instruments: neighbours' unemployment rate and the neighbours' share of welfare recipients.

\section{A.4 Maximum likelihood spatial lag estimation}

It is interesting to compare the IV-estimates to the results of alternative estimation techniques, such as ML and OLS. Since OLS and ML may suffer from different types of bias in a spatial setting, comparing the magnitudes of these estimators can tell us something about the presence and magnitude of such bias. However, ML is very 
cumbersome to apply to large panels. Therefore, we will re-estimate the baseline regression for a cross-section consisting of the average values of the variables over the time period ${ }^{58}, 1993-2003$, and compare this with the corresponding result from ML-estimation with a spatial process in the dependent variable. ${ }^{59}$

Table A.4: Baseline estimation on the cross-section of averages over 1993-2003

\begin{tabular}{lccc}
\hline \hline & OLS & ML & IV \\
& $(1)$ & $(2)$ & $(3)$ \\
\hline Neighbours' tax rate & $0.694^{* * *}$ & $0.574^{* * *}$ & $0.553^{* * *}$ \\
& $(0.071)$ & $(0.058)$ & $(0.132)$ \\
Taxable income & $0.000^{* *}$ & $0.000^{* *}$ & $0.000^{* *}$ \\
& $(0.0005)$ & $(0.0005)$ & $(0.0005)$ \\
Grants & $0.00005^{* * *}$ & $0.00006^{* * *}$ & $0.00006^{* * *}$ \\
& $(0.00002)$ & $(0.00002)$ & $(0.00002)$ \\
Unemployment rate & 0.049 & $0.082^{*}$ & 0.088 \\
& $(0.047)$ & $(0.046)$ & $(0.058)$ \\
Population size & 0.002 & 0.002 & 0.002 \\
& $(0.003)$ & $(0.003)$ & $(0.003)$ \\
Proportion of young $(0-15)$ & -0.057 & -0.051 & -0.049 \\
& $(0.052)$ & $(0.053)$ & $(0.053)$ \\
Proportion of elderly $(65+)$ & -005 & -0.002 & -0.002 \\
& $(0.028)$ & $(0.027)$ & $(0.028)$ \\
Share of welfare recipients & $0.147^{* * *}$ & $0.137^{* * *}$ & $0.135^{* * *}$ \\
& $(0.046)$ & $(0.044)$ & $(0.041)$ \\
Obs. & 283 & 283 & 283 \\
\hline
\end{tabular}

Note: The dependent variable is the municipal tax rate. Robust standard errors are shown in parenthesis. $* * *, * *$ and $*$ denote significance at the 1,5 and 10 percent level respectively. The spatial weight matrix for computing neighbours' taxes is based on sharing border and is row standardized. Instruments: neighbours' unemployment rate and the neighbours' share of welfare recipients.

The results in Table A.4 show that the ML- and the IV-estimates for the tax interaction are both positive and significant, and are relatively close to the IV-coefficient obtained in the panel-regression in Table 2. The ML-estimate is 0.57, and the IVcorrespondence 0.55 . The ML estimator is sensitive to spatial error correlation but handles the bias resulting from simultaneity in tax determination. Hence, this pattern, a larger ML-estimate, is consistent with the presence of positive spatial error correlation, giving a upward bias in the ML-estimate. The closeness of the estimates suggests this type of bias to be small, however.

Looking at the OLS-estimate we see that, contrary to the panel-case, the OLS is here larger than the IV-estimate. This is consistent with a positive simultaneity bias in the OLS-coefficient.

\footnotetext{
${ }^{58}$ The dummy variable for a left-wing majority has been excluded from this regression, since it is not clear how its average value over the period shall be interpreted.

${ }^{59}$ We have also estimated the regression for the cross-section of each year separately. The results of these regressions are similar to those when we use averages. The ML-estimate was computed using the command spatreg in Stata.
} 


\section{A.5 Alternative sets of instruments}

Table A.6 shows the baseline specification and alternative sets of instruments.. In column 1, we instrument neighbours' tax rate using the rate of unemployment, intergovernmental grants and the share of welfare recipients. In column 2 , the instruments

Table A.5: Current period instruments

\begin{tabular}{|c|c|c|c|}
\hline & $(1)$ & $(2)$ & $(3)$ \\
\hline \multirow[t]{2}{*}{ Neighbours' tax rate } & $\begin{array}{c}0.798 \\
(0.133) * * *\end{array}$ & $\begin{array}{c}0.643 \\
(0.159) * * *\end{array}$ & $\begin{array}{c}0.794 \\
(0.134) * * *\end{array}$ \\
\hline & {$[0.204] * * *$} & {$[0.251] * *$} & {$[0.207] * * *$} \\
\hline \multirow[t]{2}{*}{ Taxable income } & $\begin{array}{c}0.005 \\
(0.0007) * * *\end{array}$ & $\begin{array}{c}0.005 \\
(0.0007) * * *\end{array}$ & $\begin{array}{c}0.005 \\
(0.0007) * * *\end{array}$ \\
\hline & {$[0.001] * * *$} & {$[0.001] * * *$} & {$[0.001] * * *$} \\
\hline \multirow[t]{2}{*}{ Grants } & $\begin{array}{c}0.00002 \\
(1.00 \mathrm{e}-05) *\end{array}$ & $\begin{array}{c}0.00002 \\
(1.00 \mathrm{e}-05) *\end{array}$ & $\begin{array}{c}0.00002 \\
(1.00 \mathrm{e}-05) *\end{array}$ \\
\hline & {$[0.00002]$} & {$[0.00002]$} & {$[0.00002]$} \\
\hline \multirow[t]{2}{*}{ Unemployment rate } & $\begin{array}{c}0.022 \\
(0.012) *\end{array}$ & $\begin{array}{c}0.028 \\
(0.013) * *\end{array}$ & $\begin{array}{c}0.022 \\
(0.012) *\end{array}$ \\
\hline & {$[0.019]$} & {$[0.022]$} & {$[0.019]$} \\
\hline \multirow[t]{2}{*}{ Population size } & $\begin{array}{c}-0.096 \\
(0.028) * * *\end{array}$ & $\begin{array}{c}-0.098 \\
(0.029) * * *\end{array}$ & $\begin{array}{c}-0.096 \\
(0.028) * * *\end{array}$ \\
\hline & {$[0.067]$} & {$[0.069]$} & {$[0.067]$} \\
\hline \multirow[t]{2}{*}{ Proportion of young (0-15) } & $\begin{array}{c}0.051 \\
(0.034)\end{array}$ & $\begin{array}{c}0.031 \\
(0.037)\end{array}$ & $\begin{array}{c}0.05 \\
(0.034)\end{array}$ \\
\hline & {$[0.070]$} & {$[0.073]$} & {$[0.070]$} \\
\hline \multirow[t]{2}{*}{ Proportion of elderly $(65+)$} & $\begin{array}{c}0.133 \\
(0.028) * * *\end{array}$ & $\begin{array}{c}0.113 \\
(0.027) * * *\end{array}$ & $\begin{array}{c}0.133 \\
(0.028) * * *\end{array}$ \\
\hline & {$[0.052] * *$} & {$[0.044] * *$} & {$[0.053] * *$} \\
\hline \multirow[t]{2}{*}{ Share of welfare recipients } & $\begin{array}{l}0.007 \\
(0.014)\end{array}$ & $\begin{array}{l}0.002 \\
(0.014)\end{array}$ & $\begin{array}{l}0.007 \\
(0.014)\end{array}$ \\
\hline & {$[0.023]$} & {$[0.025]$} & {$[0.023]$} \\
\hline \multirow[t]{2}{*}{ Left-wing } & $\begin{array}{c}-0.047 \\
(0.031)\end{array}$ & $\begin{array}{c}-0.046 \\
(0.030)\end{array}$ & $\begin{array}{r}-0.047 \\
(0.031)\end{array}$ \\
\hline & {$[0.032]$} & {$[0.032]$} & {$[0.032]$} \\
\hline F-test & 8.27 & 8.76 & 11.97 \\
\hline Hansen J (p-value) & 0.618 & 0.709 & 0.483 \\
\hline Obs. & 3085 & 3085 & 3085 \\
\hline
\end{tabular}

Note: The dependent variable is the municipal tax rate. Standard errors robust to heteroscedasticity are shown in parenthesis, and standard errors robust to heteroscedasticity and serial correlation are shown in brackets. ${ }^{* *},{ }^{* *}$ and ${ }^{*}$ denote significance at the 1,5 and 10 percent level, respectively. Year and municipality-specific fixed effects are included in the estimations. The spatial weight matrix for computing neighbours' taxes is based on sharing border and is row standardized. The F-statistic is the test of excluded instruments obtained from the first-stage equation. Hansen $\mathrm{J}$ is the p-value for the Hansen test of overidentifying restrictions.

used are intergovernmental grants and unemployment rate. Column 3 is the baseline specification shown in Table 2 (instrumenting using the share of welfare recipients and the rate of unemployment).Table A.5 shows the results using the same set of instruments as in Table A.6; however, the instruments as well as the own covariates are lagged one time period. As can be seen, when comparing the F-statistic in Table A.5 and Table A.6, employing lagged local characteristics reduces the explanatory 
power of the instruments in the first-stage equation. In addition, the p-value of the Hansen $\mathrm{J}$ is higher in all specifications in Table A.6, as compared to Table A.5 with current period instruments.

Table A.6: Lagged instruments

\begin{tabular}{|c|c|c|c|}
\hline & $(1)$ & $(2)$ & $(3)$ \\
\hline \multirow[t]{2}{*}{ Neighbours' tax rate } & $\begin{array}{c}0.668 \\
(0.233) * *\end{array}$ & $\begin{array}{l}0.500 \\
(0.305)\end{array}$ & $\begin{array}{c}0.739 \\
(0.219) * * *\end{array}$ \\
\hline & {$[0.455]$} & {$[0.593]$} & {$[0.373] * *$} \\
\hline \multirow[t]{2}{*}{ Taxable income } & $\begin{array}{c}0.005 \\
(0.0009) * * *\end{array}$ & $\begin{array}{c}0.004 \\
(0.0009) * * *\end{array}$ & $\begin{array}{c}0.005 \\
(0.0009) * *\end{array}$ \\
\hline & {$[0.002] * *$} & {$[0.002] * * *$} & {$[0.002] * *$} \\
\hline \multirow[t]{2}{*}{ Grants } & $\begin{array}{l}7.05 \mathrm{e}-06 \\
(0.00002)\end{array}$ & $\begin{array}{c}5.57 \mathrm{e}-07 \\
(0.00002)\end{array}$ & $\begin{array}{c}9.79 \mathrm{e}-06 \\
(0.00002)\end{array}$ \\
\hline & {$[0.00003]$} & {$[0.00004]$} & {$[0.00003]$} \\
\hline \multirow[t]{2}{*}{ Unemployment rate } & $\begin{array}{l}0.017 \\
(0.012)\end{array}$ & $\begin{array}{l}0.020 \\
(0.013)\end{array}$ & $\begin{array}{l}0.016 \\
(0.012)\end{array}$ \\
\hline & {$[0.017]$} & {$[0.019]$} & {$[0.016]$} \\
\hline \multirow[t]{2}{*}{ Population size } & $\begin{array}{c}-0.091 \\
(0.026) * * *\end{array}$ & $\begin{array}{c}-0.092 \\
(0.027) * * *\end{array}$ & $\begin{array}{c}-0.090 \\
(0.026) * * *\end{array}$ \\
\hline & {$[0.064]$} & {$[0.066]$} & {$[0.063]$} \\
\hline \multirow[t]{2}{*}{ Proportion of young (0-15) } & $\begin{array}{c}0.037 \\
(0.040)\end{array}$ & $\begin{array}{l}0.017 \\
.048)\end{array}$ & $\begin{array}{l}0.045 \\
(0.038)\end{array}$ \\
\hline & {$[0.086]$} & {$[0.104]$} & {$[0.075]$} \\
\hline \multirow[t]{2}{*}{ Proportion of elderly $(65+)$} & $\begin{array}{c}0.092 \\
(0.039) * *\end{array}$ & $\begin{array}{c}0.069 \\
(0.045)\end{array}$ & $\begin{array}{c}0.102 \\
(0.039) * * *\end{array}$ \\
\hline & {$[0.081]$} & {$[0.089]$} & {$[0.075]$} \\
\hline \multirow[t]{2}{*}{ Share of welfare recipients } & $\begin{array}{c}-0.001 \\
(0.014)\end{array}$ & $\begin{array}{c}-0.005 \\
(0.015)\end{array}$ & $\begin{array}{c}0.0004 \\
(0.013)\end{array}$ \\
\hline & {$[0.026]$} & {$[0.031]$} & {$[0.022]$} \\
\hline \multirow[t]{2}{*}{ Left-wing } & $\begin{array}{l}-0.056 \\
(0.031) *\end{array}$ & $\begin{array}{l}-0.052 \\
(0.032) *\end{array}$ & $\begin{array}{l}-0.057 \\
(0.031) *\end{array}$ \\
\hline & {$[0.036]$} & {$[0.036]$} & {$[0.035]$} \\
\hline F-test & 3.78 & 3.48 & 5.10 \\
\hline Hansen J (p-value) & 0.853 & 0.776 & 0.611 \\
\hline Obs. & 3085 & 3085 & 3085 \\
\hline
\end{tabular}

Note: The dependent variable is the municipal tax rate. Standard errors robust to heteroscedasticity are shown in parenthesis, and standard errors robust to heteroscedasticity and serial correlation are shown in brackets. ${ }^{* * *},{ }^{* *}$ and ${ }^{*}$ denote significance at the 1,5 and 10 percent level, respectively. Year and municipality-specific fixed effects are included in the estimations. The spatial weight matrix for computing neighbours' taxes is based on sharing border and is row standardized. The F-statistic is the test of excluded instruments obtained from the first-stage equation. Hansen $J$ is the p-value for the Hansen test of overidentifying restrictions. 
WORKING PAPERS*

Editor: Nils Gottfries

2005:15 Helge Bennmarker, Kenneth Carling and Bertil Holmlund, Do Benefit Hikes Damage Job Finding? Evidence from Swedish Unemployment Insurance Reforms. 37 pp.

2005:16 Pär Holmberg, Asymmetric Supply Function Equilibrium with Constant Marginal Costs. 27 pp.

2005:17 Pär Holmberg: Comparing Supply Function Equilibria of Pay-as-Bid and Uniform-Price Auctions. 25 pp.

2005:18 Anders Forslund, Nils Gottfries and Andreas Westermark: Real and Nominal Wage Adjustment in Open Economies. 49 pp.

2005:19 Lennart Berg and Tommy Berger, The Q Theory and the Swedish Housing Market - An Empirical Test. 16 pp.

2005:20 Matz Dahlberg and Magnus Gustavsson, Inequality and Crime: Separating the Effects of Permanent and Transitory Income. 27 pp.

2005:21 Jenny Nykvist, Entrepreneurship and Liquidity Constraints: Evidence from Sweden. 29 pp.

2005:22 Per Engström, Bertil Holmlund and Jenny Nykvist: Worker Absenteeism in Search Equilibrium. 35pp.

2005:23 Peter Hästö and Pär Holmberg, Some inequalities related to the analysis of electricity auctions. 7pp.

2006:1 Jie Chen, The Dynamics of Housing Allowance Claims in Sweden: A discrete-time hazard analysis. 37pp.

2006:2 Fredrik Johansson and Anders Klevmarken: Explaining the size and nature of response in a survey on health status and economic standard. 25pp.

2006:3 Magnus Gustavsson and Henrik Jordahl, Inequality and Trust: Some Inequalities are More Harmful than Others. 29pp.

2006:4 N. Anders Klevmarken, The Distribution of Wealth in Sweden: Trends and Driving factors. 20pp.

2006:5 Erica Lindahl and Andreas Westermark: Soft Budget Constraints as a Risk Sharing Arrangement in an Economic Federation. 22pp.

2006:6 Jonas Björnerstedt and Andreas Westermark: Bargaining and Strategic Discrimination. 36pp.

\footnotetext{
* A list of papers in this series from earlier years will be sent on request by the department.
} 
2006:7 Mikael Carlsson, Stefan Eriksson and Nils Gottfries: Testing Theories of Job Creation: Does Supply Create Its Own Demand? 23pp.

2006:8 Annika Alexius and Erik Post, Cointegration and the stabilizing role of exchange rates. 33pp.

2006:9 David Kjellberg, Measuring Expectations. 46pp.

2006:10 Nikolay Angelov, Modellig firm mergers as a roommate problem. 21pp.

2006:11 Nikolay Angelov, Structural breaks in iron-ore prices: The impact of the 1973 oil crisis. 41pp.

2006:12 Per Engström and Bertil Holmlund, Tax Evasion and Self-Employment in a High-Tax Country: Evidence from Sweden. 16pp.

2006:13 Matias Eklöf and Daniel Hallberg, Estimating retirement behavior with special early retirement offers. 38pp.

2006:14 Daniel Hallberg, Cross-national differences in income poverty among Europe’s 50+. 24pp.

2006:15 Magnus Gustavsson and Pär Österholm, Does Unemployment Hysteresis Equal Employment Hysteresis? 27pp.

2006:16 Jie Chen, Housing Wealth and Aggregate Consumption in Sweden. 52pp.

2006:17 Bertil Holmlund, Quian Liu and Oskar Nordström Skans, Mind the Gap? Estimating the Effects of Postponing Higher Education. 33pp.

2006:18 Oskar Nordström Skans, Per-Anders Edin and Bertil Holmlund, Wage Dispersion Between and Within Plants: Sweden 1985-2000. 57pp.

2006:19 Tobias Lindhe and Jan Södersten, The Equity Trap, the Cost of Capital and the Firm's Growth Path. 20pp.

2006:20 Annika Alexius and Peter Welz, Can a time-varying equilibrium real interest rate explain the excess sensitivity puzzle? 27pp.

2006:21 Erik Post, Foreign exchange market interventions as monetary policy. 34pp.

2006:22 Karin Edmark and Hanna Ågren, Identifying Strategic Interactions in Swedish Local Income Tax Policies. 36pp.

See also working papers published by the Office of Labour Market Policy Evaluation http://www.ifau.se/ 